
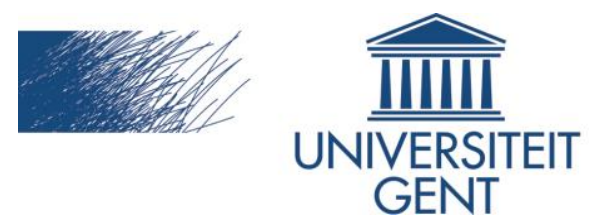

biblio.ugent.be

The UGent Institutional Repository is the electronic archiving and dissemination platform for all UGent research publications. Ghent University has implemented a mandate stipulating that all academic publications of UGent researchers should be deposited and archived in this repository. Except for items where current copyright restrictions apply, these papers are available in Open Access.

This item is the archived peer-reviewed author-version of: Challenges and strategies for the delivery of biologics to the cornea

Authors: Mike Wels, D. Roels, Koen Raemdonck, Stefaan C. De Smedt, Felix Sauvage

In: Journal of Controlled Release 333: 560-578

To refer to or to cite this work, please use the citation to the published version:

Mike Wels, D. Roels, Koen Raemdonck, Stefaan C. De Smedt, Felix Sauvage (2021)

Challenges and strategies for the delivery of biologics to the cornea

Journal of Controlled Release 333: 560-578

DOI: 10.1016/j.jconrel.2021.04.008 


\section{Challenges and strategies for the delivery of biologics to the cornea}

M. Wels ${ }^{1}$, D. Roels ${ }^{2}$, K. Raemdonck ${ }^{1}$, S.C. De Smedt ${ }^{1,3}$ and F. Sauvage ${ }^{* 1}$

${ }^{1}$ Laboratory of General Biochemistry and Physical Pharmacy, Faculty of Pharmaceutical Sciences, Ghent University, 9000 Ghent, Belgium.

${ }^{2}$ Department of Ophthalmology, Ghent University Hospital, Corneel Heymanslaan 10, 9000, Ghent, Belgium

${ }^{3}$ Joint Laboratory of Advanced Biomedical Materials (NFU-UGent), College of Chemical Engineering, Nanjing Forestry University (NFU), Nanjing 210037, P. R. China

E-mail : Felix.Sauvage@ugent.be

Tel: +3292648095

Corresponding address: Ottergemsesteenweg 460, 9000 Ghent, Belgium

Conflicts of interest: none. 


\section{Abstract}

Biologics, like peptides, proteins and nucleic acids, have proven to be promising drugs for the treatment of numerous diseases. However, besides the off label use of the monoclonal antibody bevacizumab for the treatment of corneal neovascularization, to date no other biologics for corneal diseases have reached the market. Indeed, delivering biologics in the eye remains a challenge, especially at the level of the cornea. While it appears to be a rather accessible tissue for the administration of drugs, the cornea in fact presents several anatomical barriers to delivery. In addition, also intracellular delivery barriers need to be overcome to achieve a promising therapeutic outcome with biologics. This review outlines efforts that have been reported to successfully deliver biologics into the cornea. Biochemical and physical methods for achieving delivery of biologics in the cornea are discussed, with a critical view on their efficacy in overcoming corneal barriers.

Keywords cornea, delivery barriers, transfection, gene gun, viral vectors, microneedles, nanomedicine, corneal diseases

\section{Graphical abstract}

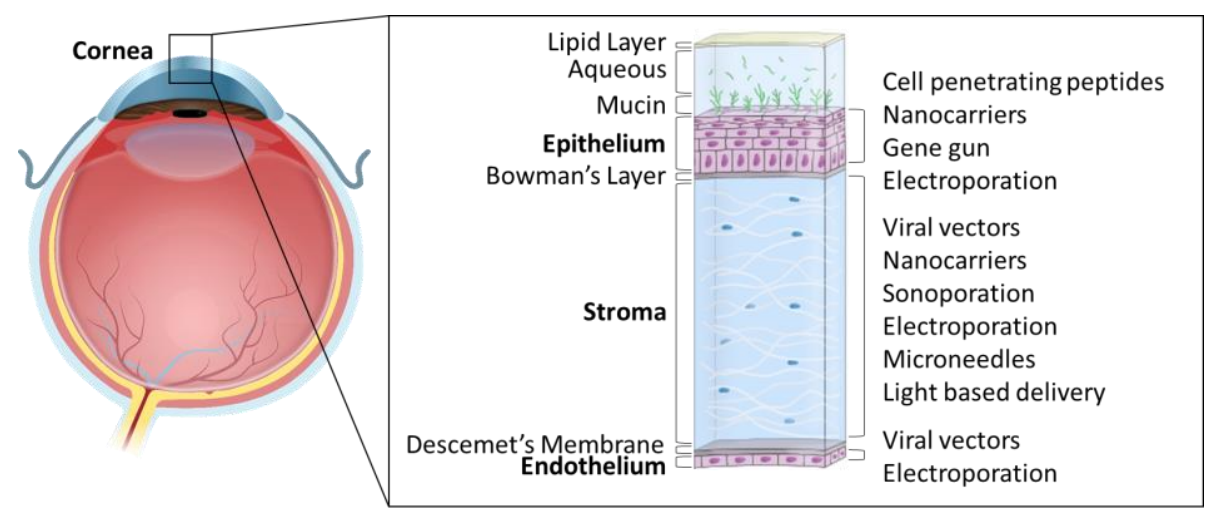




\section{Introduction}

The cornea is a clear avascular tissue located at the anterior side of the eye. It is around $560 \mu \mathrm{m}$ thick and consists of different layers, each with its own structure and barriers (Figure 1). The main role of the cornea is to refract, or bend, light in the direction of the lens and retina. Secondly, together with the neighboring sclera, it serves as an external barrier to protect the intraocular structures. Diseases at the level of the cornea can tremendously impact vision, which explains why corneal blindness is the fourth leading cause of blindness after cataract, glaucoma and age-related macular degeneration (AMD) [1]. This encompasses corneal visual impairment due to a wide variety of infectious and inflammatory diseases, mechanical injury, thermal and chemical burn, refractive errors as well as several corneal dystrophies. Quick and complete healing of the cornea is of utmost importance, however, in certain patients such as those suffering from neurotrophic keratopathy, the healing process is altered after damage resulting in persisting epithelial defects [2]. Also, the cornea of diabetic patients can exhibit a delayed wound-healing response leading to ocular surface irregularities or scarring, thus hindering clear vision [3].

Corneal blindness does not only impact normal daily life but also the mental condition of the patients. Studies have shown that only a third of the adults with a severe visual impairment report a good quality of life. Likewise, in children a moderate or severe impairment can significantly influence their quality of life $[4,5]$. For many corneal diseases, no permanent therapeutic solutions are available and corneal transplantation is therefore often needed. Currently, there is a huge unmet medical need as less than $1.5 \%$ of the transplantation needs are covered worldwide[6], due to the scarcity of good quality grafts and difficult access in developing countries[7]. Clearly, alternatives are needed to combat the unnecessary blinding. For this matter, corneal bioengineering (i.e. 3D printed corneas [8] and scaffolds[9]) or genetic strategies are extensively being explored.

In the context of corneal diseases, biologics (i.e. nucleic acid and protein drugs) offer great promise as they specifically interfere with targets and pathways[10]. Especially for treating corneal disorders nucleic acid therapeutics are of interest as in many dystrophies, which are often hereditary, specific genes need to be addressed, e.g. Meesmann corneal dystrophy (KRT3 and 12 genes) [11], Fuchs endothelial dystrophy (COL8A2 gene) [11] and epithelial recurrent erosion dystrophy (COL17A1 gene) [12]. In the healing process, specific proteins are also involved (i.e. EGF, TGF- $\beta$ and TNF- $\alpha$ for epithelial healing [13] or MyoD, to recover stromal keratocyte transparency [14]) and their function can be modulated by administering biologics to the cornea. 


\section{The barriers of the cornea}

Even though the cornea appears to be a readily available tissue for drugs by its location at the surface of the eye, its structure made of several barriers makes efficient drug delivery of biologics highly challenging. As illustrated in Figure 1B, therapeutics administered topically to the cornea have to overcome different static and dynamic barriers. The outermost barrier is the pre-corneal aqueous tear film. It serves as the primary refractive surface for light and also to moisturize and protect the cornea [15]. The tear film volume is around 7-10 $\mu \mathrm{l}$. The maximum volume of fluid the surface area of the eye can hold is $30 \mu \mathrm{l}$ due to the additional storage of the lacrimal sac. The average tear drop sizes still exceed this volume and lead to a spillover in the form of tears losing a portion of topically administered drug even before it is able to reach the ocular tissues [16]. The remainder will be diluted in the tear film, which is renewed with a turnover rate of $16 \% \mathrm{~min}^{-1}$. With the average tear film volume this converts to an average tear flow of $1.2 \mu \mathrm{min}^{-1}$ [16]. This dilution shortens the contact time of topically administered drugs with the corneal surface, as they are quickly drained through the nasolacrimal duct where they are systemically absorbed $[17,18]$. As Figure 1B shows, the tear film has an outer lipid layer that is important in tear stability [19]. In the aqueous section of the film, interaction of the drug with tear enzymes (such as lysozyme), mucins and proteins (such as albumin) can lead to non-specific binding. This binding makes drugs unable to reach their target and they are thus cleared rapidly $[20,21]$. Close to the epithelium a secreted gel, the mucin layer, can be found and acts as a barrier to pathogens [22-25]. This layer consists mostly of proteins such as MUC1, MUC4 and MUC16, which are known to be expressed by both conjunctival and corneal epithelial cells. These cell surface mucins act as lubricants and therefore as anti-adhesives for pathogens, preventing their adherence to the ocular surface [26]. It is considered as a restrictive barrier, though to which extent it is a barrier for topically applied drugs is still not clearly defined [27]. Nevertheless, it is known that trans-mucosal delivery can be difficult as the mucus layer may act as a filter (mesh size typically $<1 \mu \mathrm{m}$ [28]), while also the charge and viscoelasticity of the mucus layer might hinder drug diffusion [29]. Nevertheless, formulations with mucoadhesive features (e.g. chitosan-polyvinyl alcohol containing hydrogels [30] and sulfacetamide sodium microspheres [31]) that can interact with the mucin layer are shown to have longer retention time and improved drug absorption into the eye [31-33], suggesting the importance of this layer for drug delivery purposes and bioavailability.

As the drug dilutes into the tear film it spreads over the entire eye bulb. The complete anterior sclera and the inner side of the eyelids consist of conjunctival tissue which is, unlike the cornea, vascularized. Uptake by these tissues will in part lead to systemic absorption due to the available blood and lymphatic vessels $[17,18,34]$. Altogether, these precorneal dynamic barriers contribute to a loss of $\sim 95 \%$ of topically administered drugs. 
As Figure 1B shows, the cornea consists of five layers: the epithelium, the Bowman's membrane, the stroma, the Descemet's membrane and the endothelium.

The epithelium comprises 5-7 cell layers in various differential stages. Corneal stem cells are located in the limbal region of the eye. They allow for a continuous renewal of the basal cells, the deepest layer of the corneal epithelium [35]. The cells, as they are pushed upwards, flatten and form tight junctions forming first wing cells and lastly superficial cells. At the level of the 2-3 outermost layers, these flattened squamous superficial cells form the biggest hurdle to drug delivery. As shown in Figure 1C, there are three ways to cross the epithelium: (i) the transcellular pathway, dependent on drug size, charge and lipophilicity [36]; (ii) the paracellular pathway for small hydrophilic molecules as the pore diameter between cells of the corneal epithelium is $2.0 \mathrm{~nm} \pm 0.2$, which only allows permeation of molecules with size <500 Da [37]; and (iii) transporter-mediated permeation (e.g. CNT, SLC28 nucleotide transporter), which requires a high affinity of the drug to the transporter [38]. Due to the negative charge of the membrane of the epithelial cells, negatively charged particles or biologics such as nucleic acids can hardly cross this layer [39].

The Bowman's layer is located between the stroma and the epithelium and consists mostly of strongly layered type I and V collagen fibers. It is described as a condensation of the most anterior part of the stroma but can be distinguished from it due to a different orientation of the collagen fibers, which are randomly interwoven to form a dense sheet [40]. This layer, however, possesses relatively large pores $(\sim 10 \mu \mathrm{m})$ and is therefore not considered as a strong barrier limiting the passage of drugs or particles to the stroma [41].

The stroma is accountable for approximately $90 \%$ of the thickness of the cornea and strongly contributes to its transparency and rigidity. It consists primarily of water and collagen (mostly type I) that runs in the same alignment as opposed to the random orientation found in the bowman's layer $[42,43]$. Due to the aqueous composition of this layer it is considered to be a strong barrier for lipophilic particles. Though, the collagen fiber sieve can also hinder the diffusion of hydrophilic macromolecules in this layer [44].

The Descemet's membrane, which is located between the endothelium and the stroma, functions as a protective membrane for the endothelial layer and consists mostly of type IV collagen sheets $[45,46]$. For trans-corneal delivery the Descemet's membrane is usually not considered a limiting barrier since its estimated average pore size of $38 \mathrm{~nm}$ [47] is larger than the pores in the epithelium [41]. However, macromolecules and particles administered directly into the stroma could be prevented from reaching the endothelium [48]. 
The endothelium is a single layer of cells whose role is to maintain the water level in the stroma, thus ensuring corneal transparency and transport of nutrients. Unlike the epithelium, dead cells are not renewed in the endothelium, which makes the treatment of these cells a highly sought target for biologics. This single layer provides another minor barrier to hydrophilic particles because of the cellular composition. Even though this layer also possesses tight junctions, compared to the epithelial layer it is less limiting for drugs as it is much more leaky and discontinuous, as observed after staining with fluorescent junction markers such as ZO-1 and cadherins [49]. Due to those gaps and because the endothelium is a single cell layer, it is not considered as a significant barrier for full corneal penetration $[44,50]$.

Important to consider as well is that when biological drugs have overcome the anatomical barriers introduced above and have reached the targeted cells, they still have to overcome (intra)cellular barriers such as the cell membrane and endo-lysosomal compartments, which further limits their availability and efficacy [51].

In this review, we aim to give an overview of various delivery strategies, based on either biochemical or physical methods, that have been explored to cross the corneal barriers and deliver biologics to the different layers of the cornea (i.e. the epithelium, the stroma and the endothelium) with original examples from the literature.

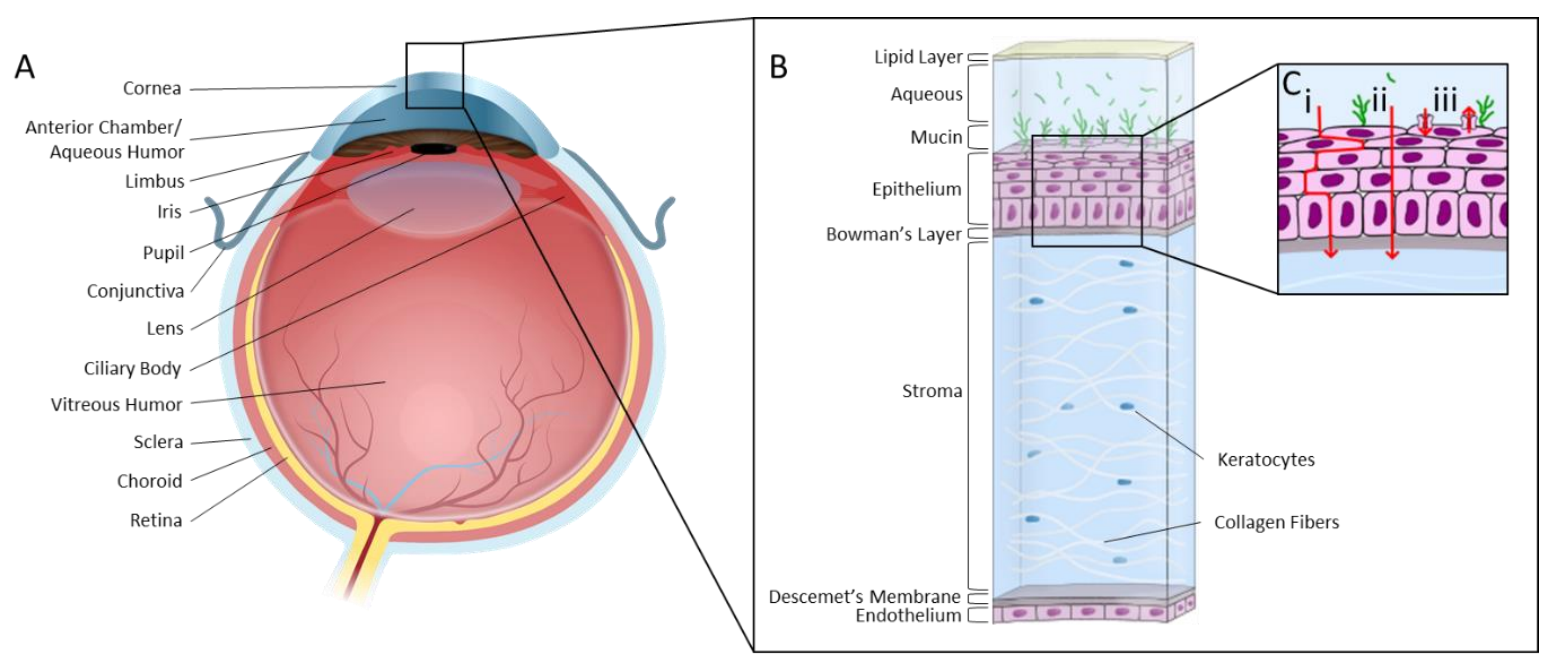

Figure 1. (A) Schematic overview of the eye. (B) Structure of the cornea. (C) The three main pathways to cross the corneal epithelium: the transcellular pathway (i); the paracellular pathway (ii); and the transporter-mediated pathway (iii). 


\section{Delivery of biologics to the corneal epithelium}

\section{1. (Bio)chemical methods to deliver biologics to the corneal epithelium}

\section{'Naked' delivery}

The most straightforward way to deliver biologics in the cornea would be the topical administration of 'naked biologics', i.e. without encapsulation of the drug in a (nano)carrier. However, this way of delivering biologics presents some limitations. First, nucleic acids/proteins are not stable as they might be degraded by enzymes that are found in the tear film $[52,53]$. Second, naked biologics have poor interaction with the ocular surface. Besides, internalization of biologics into cells has proven to be very difficult [54]. Even after cellular uptake most will be degraded in endo-lysosomes before being able to exert their function [54]. Therefore, only few examples with moderate success of naked delivery have been reported. In the context of keratitis, i.e. an inflammation of the cornea that can have an infectious or traumatic origin, naked antisense oligonucleotides, preventing insulin receptor substrate-1 expression in the corneal epithelium, were topically administered to a neovascularized cornea. Though the vessels were still present in the epithelium, the relative area of neovascularization narrowed after persisted treatment for up to 6 months [55]. The company Sylentis investigated the administration of a naked siRNA for the treatment of dry eye disease. By targeting the transient receptor potential cation channel subfamily $V$ member 1 (TRPV1), which can be found in both the corneal epithelium and the conjunctiva, it is expected to modulate sensing and transmission of pain stimuli linked to dry eye disease. In a phase $\mathrm{I} /$ Il clinical trial, a significant improvement in symptoms commonly seen with dry eye disease, such as eye sensitivity and irritation, was observed without any side effects [56]. A phase III trial concluded in 2019 showed improvements in patients through reduced pain, dryness, and itching especially in a subgroup of patients suffering from Sjögren's Syndrome [57]. If naked delivery of biologics has shown some relative success at the level of the epithelium, strategies to further improve (intracellular) delivery of biologics on the one hand and the stability in biofluids (e.g. tear film) on the other hand, are still required.

\section{Cell Penetrating peptides for ocular delivery}

Cell penetrating peptides (CPP) are usually small peptides with a maximal length of 30 amino acids [58]. They have a high rate of permeation into cells, while showing low cytotoxicity and no immunological response [58]. CPPs can be internalized in cells through two different mechanisms. The first mechanism is via direct membrane translocation, i.e. CPPs can form inverted micelles or pores at the level of the cell membrane. The second mechanism is based on endocytosis (e.g. macropinocytosis, clathrin-mediated endocytosis and caveolae-mediated endocytosis) (Figure 2A). Direct translocation allows the cargo carried by the CPPs to be delivered directly into the cytoplasm, thereby avoiding 
(degradation in) the endo-lysosomal compartment [58]. Johnson et al. initially investigated different types of CPPs for retinal delivery. They synthesized a peptide with a heparin-binding region able to interact with heparin and chondroitin sulfate found at the surface of the retina [59]. To investigate whether it is possible to deliver this peptide non-invasively, they topically administered the peptide (named peptide for ocular delivery (POD)) conjugated to the fluorescent probe lissamine and observed an enhanced corneal uptake compared to lissamine only. While naked lissamine dropped on the cornea of mice did not show any significant penetration into the corneal epithelium, lissamineconjugated POD seemed to be internalized into the epithelial cells of the cornea. Most of the fluorescence was detected in the outer layer of the epithelium indicating POD had improved contact time with the cornea. However, the fluorescence almost completely disappeared 24 hours after treatment [59]. In another study, the same group conjugated a GFP tag to the POD to investigate whether also macromolecules can be delivered in this way. While the naked GFP protein did not seem to be taken up by the cells, GFP-POD fusion protein resulted in fluorescent signals in the corneal epithelial cells of mice. The fluorescence was mostly seen in the epithelial layers but a very faint signal was also detected in the most anterior part of the stroma suggesting POD might have potential to deliver peptides and proteins in various layers of the corneal epithelium [60]. 


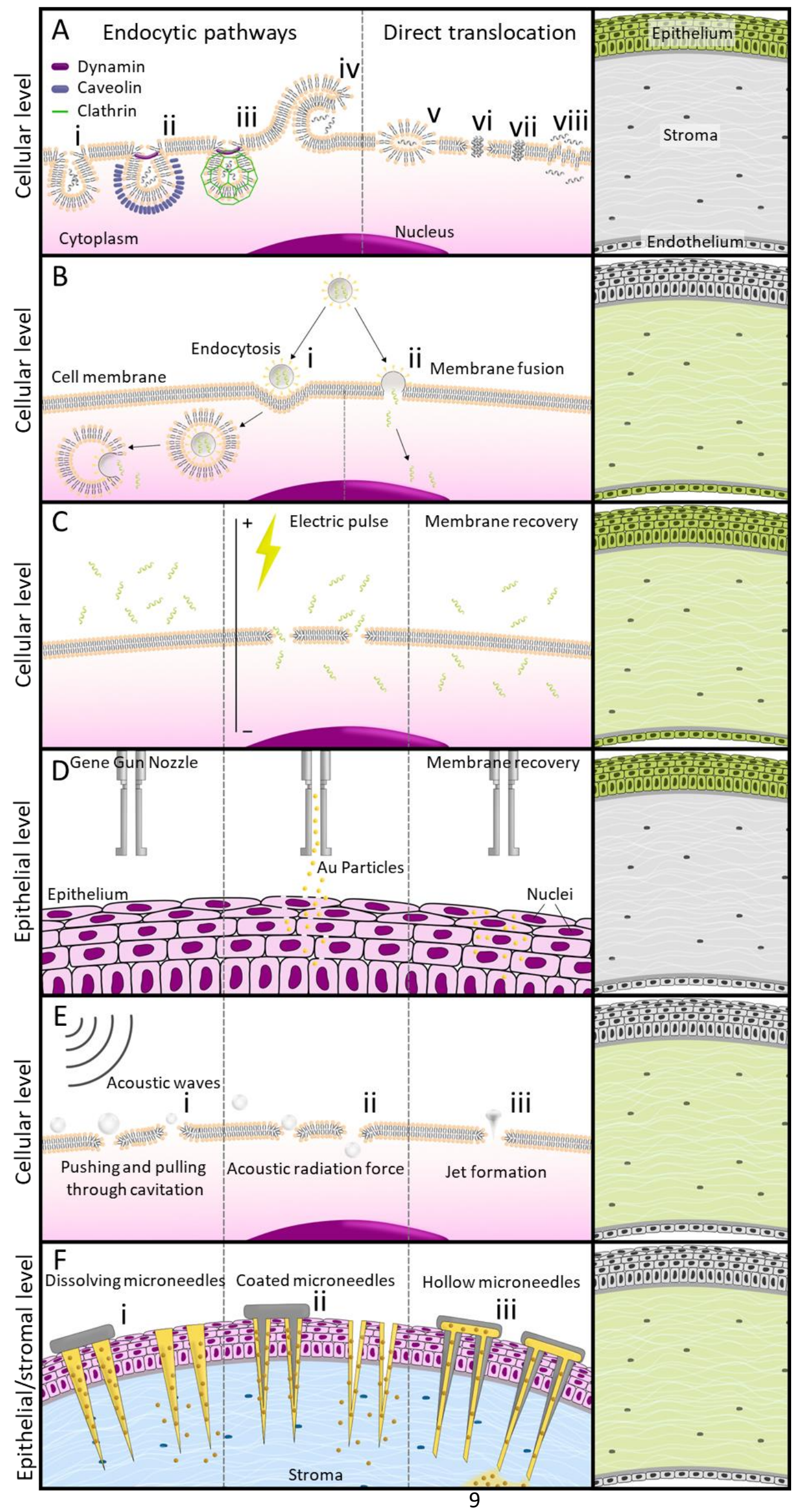


Figure 2. Biochemical and physical methods for corneal delivery of biologics. In the right panels, green layers (epithelium, stroma and endothelium) in the cornea indicate where the different methods have been successfully used for the delivery of biologics. (A) Cell penetrating peptide can be used to deliver drugs through different types of entry into the cell: clathrin- and caveolae-independent endocytosis (i), caveolae-mediated endocytosis (ii), clathrin-dependent endocytosis (iii), macropinocytosis (iv), inverted micelle (v), barrel-stave pore (vi), toroidal pore (vii) and carpet formation (viii). (B) Viral vectors are able to enter cells by endocytosis and followed by endosomal escape (i) or by fusing with the membrane (ii). (C) Electroporation uses electric fields to transiently create pores in cell membranes which allows diffusion into the cells. (D) Gene gun delivery employs coated micro particles that are propelled under pressure towards a tissue. The high pressure allows the particles to perforate the membranes which are quickly closed after treatment. Distance between gene gun and cornea and pressure can be adjusted to target different epithelial layers. (E) Sonoporation is a method where ultrasound waves are used to cavitate microbubbles to form pores. Expansion and shrinking of bubbles under the influence of acoustic waves pull and push on the cell membrane causing transient pore formation (i). Waves are able to push bubbles against the membrane, with enough force it can cause it to be pushed through the membrane and form pores (ii). When the bubble collapses a liquid jet can be formed which punctures the membrane (iii). (F) Microneedles are able to penetrate the epithelium and enter the stroma. Microneedles are embedded in the cornea and start dissolving to release the drug (i). Drug-coated microneedles dissolve into the stroma (ii). Hollow microneedles can be used to directly inject liquid formulations into the stroma (iii).

Although POD is attractive for the delivery of biologics into the cytoplasm, a portion of the conjugates remains internalized into the endo-lysosomes where it most likely degrades [58]. Our group has recently shown that cationic amphiphilic compounds, with many of them used as drugs (e.g. antihistaminics, antidepressants, antihypertensives), are able to facilitate lysosomal escape of nucleic acid drugs [61-63]. Schiroli et al. explored other avenues to improve endo-lysosomal escape of siRNA carried by POD (Figure 3) in the corneal epithelium. Either palmitoyl (PALM) or cholesteryl groups were conjugated at the $\mathrm{N}$-terminus of the POD to increase the hydrophobicity of the peptides and aid in the destabilization of the endosomal membrane. This improved the delivery of fluorescently labeled siRNA in the corneal epithelium of mice. Interestingly, palmitoylation showed 3-4 times higher transfection efficiency (Figure 4A). To further improve cytosolic delivery, they added chloroquine (a cationic amphiphilic drug known to induce lysosomal membrane permeabilization) one hour before transfecting the cells with PALM-POD complexed with anti-luciferase siRNA. The authors confirmed this improved the knockdown of luciferase in vitro in human corneal epithelial cells (HCE-S) [64]. As chloroquine is known for its ocular toxicity [65] it was replaced with the better tolerated 
trifluoromethylquinoline (QN). Functionalizing PALM-POD with this compound resulted in a significant knockdown of a luciferase reporter gene (up to 30\%) in vivo in the corneal epithelium of transgenic mice, which could be observed for 72 hours after treatment. Also, the knockdown was seen in deeper layers of the cornea suggesting this method could be employed to reach stromal cells via topical administration [64].

\section{CGGG $[\text { ARKKAAKA }]_{4} \quad P O D$}
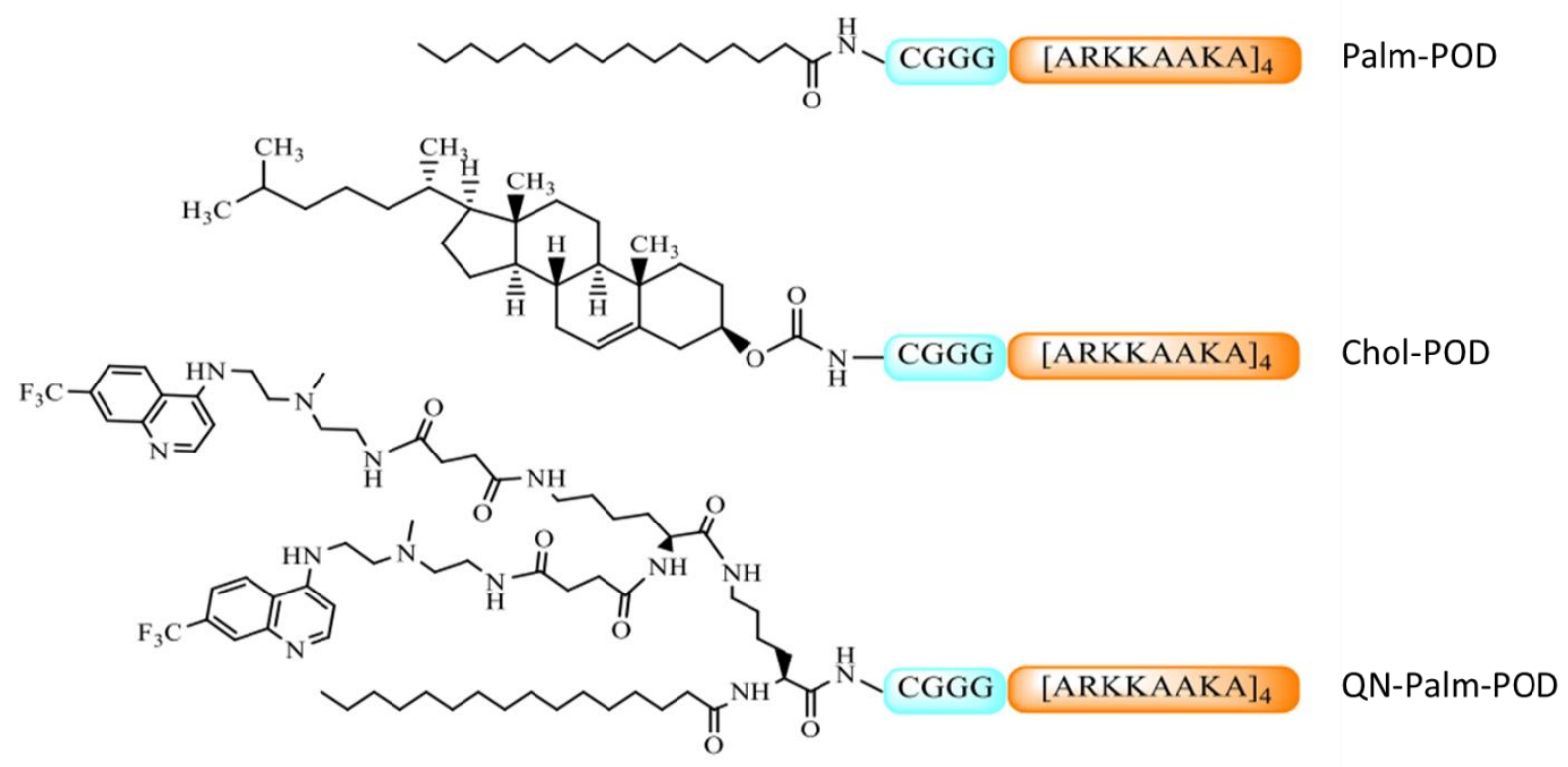

Figure 3. Structural representation of peptide for ocular delivery (POD) conjugates. Palm= Palmitoyl, Chol=Cholesteryl and QN=trifluoromethylquinoline (adapted from [64]).

\section{Non-viral vectors}

To improve corneal wound healing, Zahir-Jouzdani et al. explored polyethylenimine (PEI) to deliver siRNA targeting TGF- $\beta 1$ [66]. PEI is a positively charged polymer that is commonly used to form complexes with negatively charged nucleic acids [67]. In an alkali burn mouse model, after 21 days of treatment with these polyplexes, angiogenesis and fibrosis could no longer be detected. Complexing siRNA with PEI led to an improved internalization into the fibroblasts that migrate to the epithelium after corneal wounding. However, a slight inflammatory response in the treated group was observed, which was most likely attributed to PEI [66]. As PEI is generally considered as a toxic polymer, mainly due to its strong cationic charge density, it might not be an optimal excipient for ocular delivery of nucleic acids [68]. 
Baran-Rachwalska et al. investigated topically applied biodegradable silicon/lipid nanoparticles (SiNPs; named ProSilic) to deliver (fluorescent) siRNA into corneal epithelial cells in mice [69]. Different lipid mixtures were explored (including DOPE and DC-chol). Fluorescent siRNA was complexed to the nanoparticles, which were topically applied on a mouse cornea. Compared to naked siRNA, the uptake was twice as high and reached maximal levels already 15 minutes after administration. Depending on the lipids used, which changes charge and loading capacity of the silicon/lipid nanoparticles, a fluorescence signal could still be detected in the cornea after 24 hours (Figure 4B). Subsequently, luciferase-targeting siRNA packaged in ProSilic nanoparticles was topically applied daily in a reporter knock-in mouse model. A significant reduced luciferase expression could be observed within 24 hours after the first administration and lasting up to four days after the end of the treatment with a maximum inhibition of $41 \%$ at day 11 [69].

\section{Viral vectors}

Viral vectors are commonly used for gene therapy. Their natural ability to transduce genetic information into host cells can be exploited by exchanging their genes by transgenes of choice (Figure 2B). Many types of viruses are of interest e.g. retrovirus, lentivirus, adenovirus and herpes simplex virus), each showing advantages and drawbacks (i.e. gene capacity, immunogenicity, tropism, being able to transduce non-dividing cells) [70]. In recent years, several drugs using viral vectors were approved, including Luxturna (AAV2 vector subretinally injected in patients with a biallelic RPE65 mutation-associated retinal dystrophy, such as Leber's congenital amaurosis [71]), Zolgensma (AAV9 vector intravenously infused to treat spinal muscular atrophy [72]) and Zynteglo (intravenous infusion of a lentiviral vector for the treatment of beta thalassemia [73]). A main concern of viral vectors, however, is related to their immunogenicity and cytotoxicity. Other concerns are the large scale GMP manufacturing costs and [74] the possible mutational insertions which can lead to activation of protooncogenes or insertional inactivation of tumor suppressors genes. Though, as the transfection efficiency of viral vectors is high compared to non-viral vectors [70], viral vectors remain attractive for ocular (including corneal) gene delivery.

Delivering a reporter gene in an adenovirus vector by eye drops has shown disappointing results since mostly no or poor expression could be observed in the corneal epithelium or in the conjunctival cells $[75,76]$. This can be likely explained by the fact that the vectors stayed entrapped into the mucin layer. Indeed, Tsubota et al. showed that mechanically removing the mucus layer of the corneal surface with a cotton swab resulted in a better expression of the reporter gene lacZ when delivered with an adenovirus (AV) type 5 in the conjunctival cells but not in the corneal epithelium [75]. Reaching higher 
expression levels in the corneal epithelium would likely require higher $\mathrm{AV}$ concentrations, which could possibly lead to toxic levels in the conjunctival cells as these cells are more easily transfected [75].

In a similar experiment, Spencer et al. treated intact mouse and rat eyes in vivo with a Herpes simplex virus-1 vector expressing lacZ and observed no expression after topical administration. However, when scarring the cornea with a 30-gauge needle before treatment, expression of lacZ was observed in the epithelial layer of both mice and rats [77].

In an effort to improve residence time and transfection efficiency of topically applied adenoviruses, Wang et al. functionalized adenoviruses with chitosan [76]. Indeed, it is known that chitosan, owing to its mucoadhesive properties, prolongs residence time of e.g. polymeric nanoparticles at the surface of the eye $[78,79]$. This modified vector was used to deliver GFP-encoding pDNA in vivo into the epithelial cells of rats. Rats treated with the chitosan-conjugated vector showed a more intense fluorescent signal along the full corneal epithelium, relative to its unmodified counterpart [76].

\section{Physical methods to deliver biologics to the corneal epithelium}

Using physical methods (i.e. involving external stimuli such as pressure, ultrasound, electric fields), it might be possible to efficiently bypass the tear film and the tight junctions of the epithelium, while also improving the (intracellular) delivery of biologics.

\section{Electroporation}

Electroporation applies an electric field to form pores in cell membranes. The cell membrane has a low electric potential. Therefore by increasing the transmembrane potential with short low electric pulses, it is possible to (transiently) re-orientate membrane lipids, thereby forming small pores that allow molecules to diffuse into cells $[80,81]$ (Figure 2C). Electroporation over the anterior section of the cornea following intrastromal injection of pDNA has been successful in expressing luciferase and IL-10 in the epithelium layer $[82,83]$. Expression of luciferase could be detected as early as 6 hours post treatment, across the entire cornea. Blair-Parks et al. also investigated the effectiveness of epithelial transfection with electroporation after a subconjunctival or intrastromal injection of luciferase pDNA in mice. Electroporation after subconjunctival injection led to a higher initial expression of luciferase in several layers of the epithelium, albeit it showed a faster decline compared to intrastromal injection. With both injection methods, luciferase expression was still detected after 7 days (Figure 4C). While a voltage of $200 \mathrm{~V} / \mathrm{cm}$ was sufficient to achieve delivery without inducing ocular tissue damage, higher voltages $(\geq 400 \mathrm{~V} / \mathrm{cm}$ ) led to visible damages such as corneal edema [82]. 


\section{Gene gun}

Gene gun is mostly employed to deliver nucleic acids into cells [84]. Though gene gun has been extensively studied in vitro to transfect cells, it has also been investigated for in vivo transfection of corneal epithelial cells [85-90]. Gene gun uses nano- or microparticles, usually gold, coated with nucleotides that will be propelled into cells or tissues. An inert gas such as helium is used to propel the particles allowing them to penetrate cell membranes or travel through a tissue [91] (Figure 2D). Exploring gene gun for transfection of corneal epithelium, Zhang et al. observed that it is critical to adjust both the distance between the nozzle and the front of the eye and the force applied on the drug loaded particles. Important to mention is that wrong settings (e.g. high pressure) may permanently damage corneal tissue leading to erosion and neovascularization [86]. As one can expect, a longer distance between the gene gun and the cornea causes less severe defects of the corneal surface [86] and allows spontaneous recovery. Higher forces led to a deeper penetration of the particles in the corneal epithelium [86]. Besides crossing barriers, a strong advantage of gene gun is the possibility to bypass lysosomal degradation through direct delivery into the cytosol [91]. Successful gene gun experiments showed delivery of plasmid DNA encoding for interleukins (IL) in the epithelium $[86,87]$. Bauer et al. succeeded in expressing IL-4 and IL-10 to moderate the progress of herpetic stromal keratitis without interfering with other local immune responses [87]. These authors observed that gene gun treatment can lead to a mild inflammation in the limbal region. Most of the particles (respectively $0.6 \mu \mathrm{m}$ and $1.6 \mu \mathrm{m}$ ) were found in the epithelial layers with some in the anterior segment of the stroma (Figure 4D). It was also noticed that, after 14 days, most of the gold particles were cleared from the epithelium, probably due to the high turnover rate of epithelial cells [87]. In both studies, production of ILs by corneal epithelial cells could be induced without any serious side effects. All these examples showed gene gun delivery leads to very local delivery without affecting other tissues and might thus be well suited for delivering biologics to the corneal epithelium. 

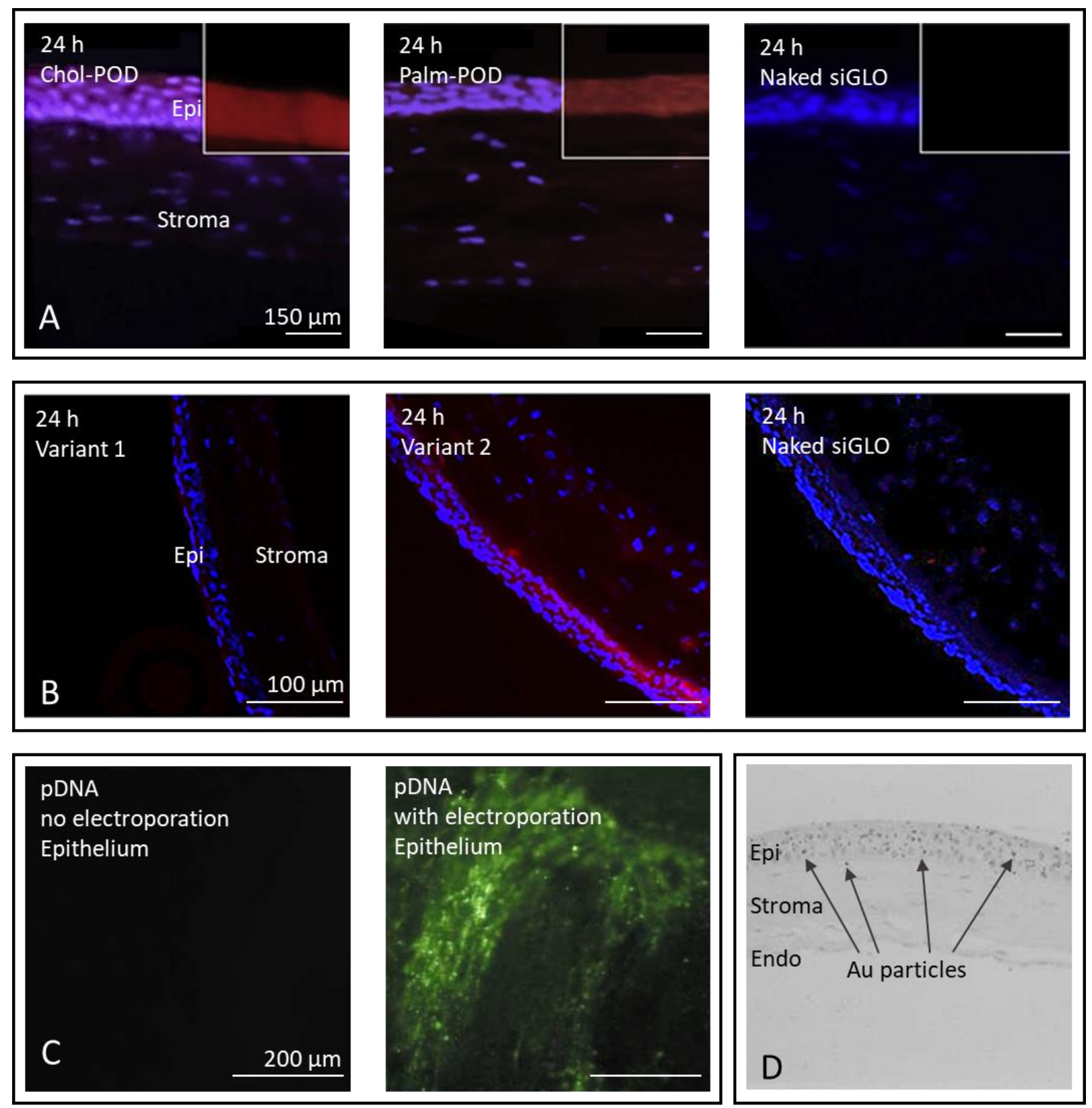

Figure 4. Delivery of biologics into the corneal epithelium. (A) POD (being peptides for ocular delivery) are able to efficiently deliver fluorescently labeled siRNA (siGLO, red signal) into the epithelial layer of the cornea; naked siGLO (right panel) does not transfect the epithelial cells [64]. (B) 24 hours after treatment silicon/lipid nanoparticles (ProSilic) successfully transfected corneal epithelial cells (red fluorescent siGLO) when DOPE:DC-chol:stearylamine were used as lipids [69]. (C) Luciferase expression in clearly visible in the corneal epithelium following electroporation of the cornea [82]. (D) Following gene gun treatment, gold particles (black dots) are able to penetrate different layers of the corneal epithelium ((original magnification $\times 250)$ [87]. Adapted from $[64,69,82,87]$. 


\section{Delivery of biologics to the stroma}

Reaching the stroma after topical administration of drugs is generally difficult because of the upstream epithelial barriers. However, it is an interesting target as it is where several dystrophies originate, e.g. congenital stromal corneal dystrophy (decorin gene), macular corneal dystrophy (carbohydrate sulfotransferase 6 gene) and Fleck corneal dystrophy (phosphoinositide kinase gene) [11]. The main cellular targets are the keratocytes, which are able, in response to damage, to differentiate into repair fibroblasts [13]. The stroma is also an important therapeutic target for treating neovascularization as it is the siege of many of the newly formed blood vessels [92].

\section{1. (Bio)chemical methods to deliver biologics to the stroma}

\section{Naked delivery}

During corneal neovascularization (due to e.g. trauma, infection and inflammation), new vessels originate from the capillaries and venules of the pericorneal plexus under the influence of proangiogenic factors such as vascular endothelial growth factor (VEGF), basic fibroblast growth factor and matrix metalloproteinases. Rapid therapeutic management is important, as when new blood vessels are making their way into the stroma it loses its transparency. VEGF is seen as an interesting therapeutic target as it plays an important role in vessel formation [92]. In the stroma, VEGF is primarily produced by inflammatory cells such as macrophages but it can also be produced by keratocytes during inflammation [93]. To inhibit neovascularization, Zuo et al. subconjunctivally injected naked siRNA against VEGF-A in an alkali burn mouse model. They showed reduced VEGF levels compared to saline injections, hence downsizing the neovascularized area and vessel formation in the stroma. This effect was observed until the end of the study (30 days) [94]. Singh et al. investigated a similar setup, using naked siRNA against VEGF in an alkali burn mouse model, but this time injected intrastromally. A week after injury, VEGF levels were decreased (> $50 \%$ ) compared to control mice and the neovascularized area was significantly smaller [95].

\section{Non-viral vectors}

As neovascularization leads to new blood vessels in the stroma, Kim et al. suggested to reach the stroma via systemic administration of drugs [96]. Indeed, the leakiness of blood vessels in tumors and inflamed tissues has been well investigated $[97,98]$ and it is believed that it may locally enhance extravasation of drugs. These authors compared subconjunctival and systemic injections of respectively naked siRNA and siRNA nanoencapsulated in TargeTran (i.e. PEG-conjugated-PEI coupled with RGD [99]) with the aim to deliver a cocktail of 3 siRNA's against the VEGF pathway factors VEGFA, VEGFR1 and VEGFR2. TargeTran was previously successfully used in studies to deliver siRNA targeting 
tumor angiogenesis [96]. Both methods led to the inhibition of new blood vessel formation, although subconjunctival treatment was more effective likely due to opsonization and first pass degradation following systemic administration. Rodier et al. used linearized PEI to form polyplexes with GFP-pDNA. As it is difficult to cross the corneal epithelium, the authors removed the epithelium layer of the mice. While topical application of naked pDNA did not transfect the cells, the topically applied polyplexes were able to transfect keratocytes in the anterior and middle part of stroma [100].

Luis de Redín et al. investigated the use of albumin nanoparticles to improve topical delivery of bevacizumab to reach the stroma using a chemical burn rat model. [101] Bevacizumab targets VEGF and is used to inhibit neoangiogenesis in cancers. However, it is also used as an off label drug in the treatment of corneal neovascularization [102] and neovascular age-related macular degeneration for which it is intravitreally injected [103]. Topically applied naked bevacizumab reduced the area affected by neovascularization by $11 \%$ at day 7 . When encapsulated in albumin nanoparticles or PEG-albumin nanoparticles the affected area decreased by $61 \%$ and $38 \%$, respectively. This might be due to the albumin particles being able to adhere to the mucus layer. The authors argued that PEGylating the particles probably slightly hindered this interaction which might explain the lower effect [101].

In another example, Sun et al. investigated whether mesoporous silica nanoparticles could improve delivery of bevacizumab in the stroma in an alkali burn mouse model. Free bevacizumab and encapsulated bevacizumab were injected subconjunctivally, which led to a reduction of vascular length around $80 \%$ and $90 \%$ respectively at day 14 . Due to the porous nature of the particles the bevacizumab was slowly released from the particles explaining the improved efficacy compared to free bevacizumab [104].

\section{Viral vectors}

As reported above, administering drugs directly into the stroma is possible via intrastromal injection. For this purpose, Carlson et al. explored adenoviral carriers that were intrastromally injected in mice to transfect stromal keratocytes with GFP pDNA. GFP could be observed in the stroma 11 hours after a single injection while a faint GFP signal could still be detected on day 21. Following intrastromal injection of naked pDNA also keratocytes became transfected though GFP expression was found to be lower. Authors suggested that the injection of naked pDNA transfected keratocytes due the pressure at the injection spot, which might permeabilize the keratocytes to some extent. Though the Descemet's and Bowman's membranes are usually not seen as barriers, no GFP signal could be detected neither in the epithelium nor in the endothelium in this study [105].

To improve stromal cell transfection following intrastromal injection, Lu et al. investigated 14 different serotypes of rAAV expressing eGFP in mice. The serotypes differed in their capsid proteins, possibly 
altering their means of entry into cells. Authors found that serotypes rAAVrh.8, rAAVrh.10, rAAVrh.39, and rAAVrh.43 were able to efficiently transduce keratocytes after intrastromal injection. These 4 serotypes were then investigated in their ability to transfect keratocytes following topical administration. It was found that topical administration on corneas with intact epithelium did not lead to any transfection. After scraping the epithelium, the serotypes rAAVrh.10 and rAAVrh.39 were shown to pass the Bowman's membrane and able to successfully transfect keratocytes in the stroma without adverse effects [106]. In a follow-up study, the same group compared intrastromal and subconjunctival injections of rAAVrh.10 vectors in an alkali burned induced neovascularization mouse model. In both healthy and damaged mouse corneas, eGFP signal was observed for a week after treatment, with both administration routes proving to be equally effective. However, two weeks after administration, the expression in damaged cornea was drastically lower than in healthy corneas (Figure 5A). With the knowledge that in the first week of treatment transfection is still effective, they delivered microRNAs (miRNA) through rAAVrh.10 vectors against genes (hey2, gjc1, rasip1, and amot) involved in neovascularization. Both administration routes allowed the miRNA to reach the entire cornea and to normalize the biological pathways that led to vascularization, thus resulting in a significant decrease of vascularized areas. However, as neovascularization originates from the limbal area, subconjunctival injections are preferred as newly forming vessels can directly be addressed likely due to the proximity of the subconjunctival tissue to the limbus [107]. Also Hippert et al. showed that the serotype of adenoassociated viruses influences transduction of cells after intrastromal injection. When examining 4 AAV2 types, the subtype AAV2/8 was found to be most efficient in transfecting keratocytes with eGFP pDNA in mice. eGFP expression in the stromal cells was still visible until 17 months after a single injection. Interestingly, eGFP expression could get a temporary boost after a sequential injection of both lipopolysaccharides (LPS) but also PBS. The authors argue that the injection itself causes an inflammatory response, able to promote gene expression levels [108]. The exact mechanism behind this remains unknown, however, in an earlier study Tsai et al. noticed this effect as well in the endothelial layer. They hypothesized that AAV-mediated gene expression is facilitated by the host cell's DNA repair process as a result of inflammatory DNA damage [109].

As seen above, intrastromal injection is of interest. However, this type of injection presents some variability while often a poor repeatability is observed. Gilger et al. investigated if by using a microsized needle these variations can be overcome. First, they investigated stainless steel microsized needles of various lengths in an ex vivo porcine eye. Depending on the length of this type of needle different depths in the stroma could be reached. They then compared intrastromal injections of AAV vectors (GFP pDNA) with a $8 \mathrm{~mm}$ needle to injections with a microsized needle (318 $\mu \mathrm{m}$ long) in rabbits. No significant difference was observed in GFP expression between the two methods. However, injections 
with microsized needles were more accurate and led to less anterior chamber penetration and leakage, which further strengthens the possibility to lower the variability and improve safety of intrastromal delivery [110].

Gupta et al. used an AAV5 vector to topically deliver the Smad7 gene to stromal cells to inhibit corneal haze formation after photorefractive keratectomy. Hereto a rabbit corneal injury model with an epithelium scraped cornea was applied. The Smad7 protein negatively regulated TGF $\beta$ signaling during corneal wound healing. In an injured state, the TGF $\beta$ downstream signaling is altered, which results in corneal scarring. Both treated and non-treated eyes showed a corneal haze, albeit treated eyes showed relatively less cloudiness and haze. A reduced expression of $\alpha$-SMA and fibronectin (two markers of scar formation) were observed in the treated group 4 weeks after treatment, suggesting the vectors successfully reached their target. This treatment seemed safe as no immune cell infiltration could be detected [111].

Finally, Yu et al. showed recombinant adenoviruses injected into the aqueous humor were also able to reach the stroma. This suggests adenoviruses are able to cross the endothelial layer and the Descemet's membrane in corneas with neovascularization [112].

\section{Physical methods to deliver biologics to the stroma}

\section{Sonoporation}

Ultrasound has been established as noninvasive and safe clinical imaging tool for decades. Sonoporation makes use of such ultrasound waves to porate cells and deliver cargos into cells $[113,114]$. Also microbubble-assisted sonoporation is under investigation for drug delivery [115]. Under the influence of ultrasound waves the gas core of the microbubbles can shrink and grow. Both the pressure of such stably oscillating bubbles as well as the force generated when the microbubbles collapse can be harnessed to create pores in cell membranes [113,114] (Figure 2E).

Sonoda et al. injected a mixture of microbubbles and GFP pDNA into the stroma of rabbits to transfect keratocytes. Applying ultrasound, the microbubbles were oscillating, which improved the transfection of keratocytes. Using low intensities $\left(<2 \mathrm{~W} / \mathrm{cm}^{2}\right)$, no apparent damages were observed at the level of the stroma or surrounding tissues and most of the transfected cells were located around the injection spot (Figure 5B) [116]. Increasing the ultrasound intensity $\left(>3 \mathrm{~W} / \mathrm{cm}^{2}\right)$ induced stromal opacity but this was resolved without any further treatment. The transfected cells displayed increasing GFP expression for 8 days after which the GFP expression decreased slowly and disappeared completely 30 days after treatment [116]. 


\section{Electroporation}

Applying electric pulses after an intrastromal administration of pDNA has successfully transfected keratocytes [82,117]. As reported above, Blair-Parks et al. investigated corneal transfection with electroporation following an intrastromal injection of naked luciferase pDNA in mice. In this way they were not only able to transfect the corneal epithelium but also stromal cells. Expression could be detected 7 days after the treatment. A voltage of $200 \mathrm{~V} / \mathrm{cm}$ for $10 \mathrm{~ms}$ was sufficient to achieve delivery without inducing ocular tissue damage [82]. Oshima et al. could also detect GFP expression in the stroma of rats for up until 15 days using $20 \mathrm{~V}$ pulses $(50 \mathrm{~ms})$ without any apparent damage after an intrastromal injection of naked GFP pDNA. Increasing the voltage above $40 \mathrm{~V} / \mathrm{cm}$ increased the number of inflammatory cells and led to neovascularization [117].

\section{Microneedles}

Kim et al. investigated the potential of microneedles in delivering the monoclonal antibody bevacizumab into the stroma of rabbits. They induced neovascularization by inserting a silk suture into the stroma near the limbus. Solid microneedles (Figure 2F) (400 $\mu \mathrm{m}$ in length, $150 \mu \mathrm{m}$ in width, $75 \mu \mathrm{m}$ in thickness) were coated with labelled and non-labeled bevacizumab and were compared with topical administration and subconjunctival injection. Microneedles and subconjunctival delivery both led to the highest reduction of neovascularization (65\% and $62 \%$ at day 10 and $62 \%$ and $29 \%$ at day 18 respectively) compared to non-coated microneedles (i.e. without bevacizumab). However, the dose needed to reach this effect with a subconjunctival injection was more than 550 times higher than the one delivered with the microneedles. Also, hollow microneedles, which can be filled with a drug solution in their core, were compared to coated solid needles. Though the amount of bevacizumab that could be administered with hollow needles $(50 \mu \mathrm{g})$ was higher than with coated microneedles (4.4 $\mu \mathrm{g})$, reduction of the vascularized area did not improve further. The authors argued this could be due to the spreading of the solution after administration while the solid microneedles slowly dissolve, the latter which maintains high bevacizumab levels more locally in the critical area. The microneedles did not induce corneal opacification or any other visible adverse effects [118].

As another example, Than et al. investigated 'double layered' microneedles. Microneedles can be made from hyaluronic acid, albeit they dissolve fast resulting in a burst release of the drug. Functionalizing hyaluronic acid with methacrylic anhydride provides a slower release, however, the stiffness of such microneedles is not optimal. The authors therefore proposed to design microneedles with a rigid fast dissolving core and an outer shell allowing a slower release. Such microneedles were embedded in the cornea aimed to act as a depot (Figure 5C). DC101 (an anti-VEGFR2 monoclonal 
antibody) was incorporated between the fast bursting core and the slow release outer shell (Figure 2F). In a chemical burn mouse model, treated eyes showed a reduction of $90 \%$ of the vascularized area while topical administration only led to a reduction of $44 \%$ compared to non-treated eyes. Subsequently diclofenac was incorporated in the fast dissolving core while the shell was loaded with DC101. This combination therapy led to a vascularized area of $0.16 \mathrm{~mm}^{2}$ while diclofenac only and DC101 only resulted in a vascularized area of $0.63 \mathrm{~mm}^{2}$ and $0.52 \mathrm{~mm}^{2}$, respectively. There were no visible adverse effects such as opacity, inflammation or hemorrhage found in the cornea after treatment [119].

\section{Gene gun}

As reported above, gene gun at higher pressure can lead to deeper penetration of (gold) nanoparticles in the cornea $[87,88]$. Only few examples report on gene gun for the delivery of biologics into the stroma. For instance, Shiraishi et al. observed pDNA-coated gold nano- and microparticles (respectively $0.6 \mu \mathrm{m}$ and $1.6 \mu \mathrm{m}$ ) only in the anterior part of the stroma. Authors explained that the high density of collagen fibers in the stroma, but also the low amount of keratocytes, limit the probability that cells in the stroma become affected by the particles. Authors therefore concluded that gene gun is not a promising approach to efficiently transfect stromal cells [88].

\section{Light-based delivery}

Pulsed-lasers and more particularly femtosecond lasers are commonly used in ophthalmology to ablate tissues (e.g. for corneal ablation $[120]$ or cataract surgery $[121,122])^{96}$. Even though they have been shown to transfect retinal ganglion cells in vivo [124] or to destroy vitreous opacities ex vivo (i.e. vitreous floaters) [125], surprisingly only few examples on the exploration of light for corneal drug delivery are reported.

Using pulsed-lasers it is possible to form (transient) pores in cell membranes, which is under investigation to deliver cargos in cells [126-128]. Also, pulsed-lasers are under investigation to form pores in tissues such as nails [129] and skin [130]. Bemelmans et al. followed this idea to form a 'pocket' in the stroma to serve as a reservoir for lentiviral vectors. After the pocket was created at a depth of $110 \mu \mathrm{m}$ from the epithelium, lentiviral vectors expressing GFP were injected into it. The pockets were naturally closed after 5 days. Lentiviral vectors expressing GFP and injected in the pocket could transduce $90 \%$ of the keratocytes surrounding the pocket whereas $53 \%$ of the keratocytes were transduced after intrastromal injection (Figure 5D) [131]. Interestingly, the expression was still visible after 21 days. However, in this study, the authors did not mention the laser fluence that was applied. Pallikaris et al. described a case study where a similar 'corneal pocket' close to a corneal abscess was created in a patient to treat a recurring deep stromal keratitis [132]. This facilitated direct delivery of 
antibiotics and an antifungal therapy, which after standard topical application had no effect. Therefore, a $380 \mu \mathrm{m}$ deep pocket was created using a laser energy of $1.3 \mu \mathrm{J}$. The compounds, moxifloxacin and voriconazole, were then injected into the pocket. Improvements such as less dense abscesses, less edema in surrounding tissues and absence of epithelial defects were observed after 5 days suggesting this type of strategy has merit and could be further investigated for the delivery of biologics into the stroma, especially to induce local sustained release. 

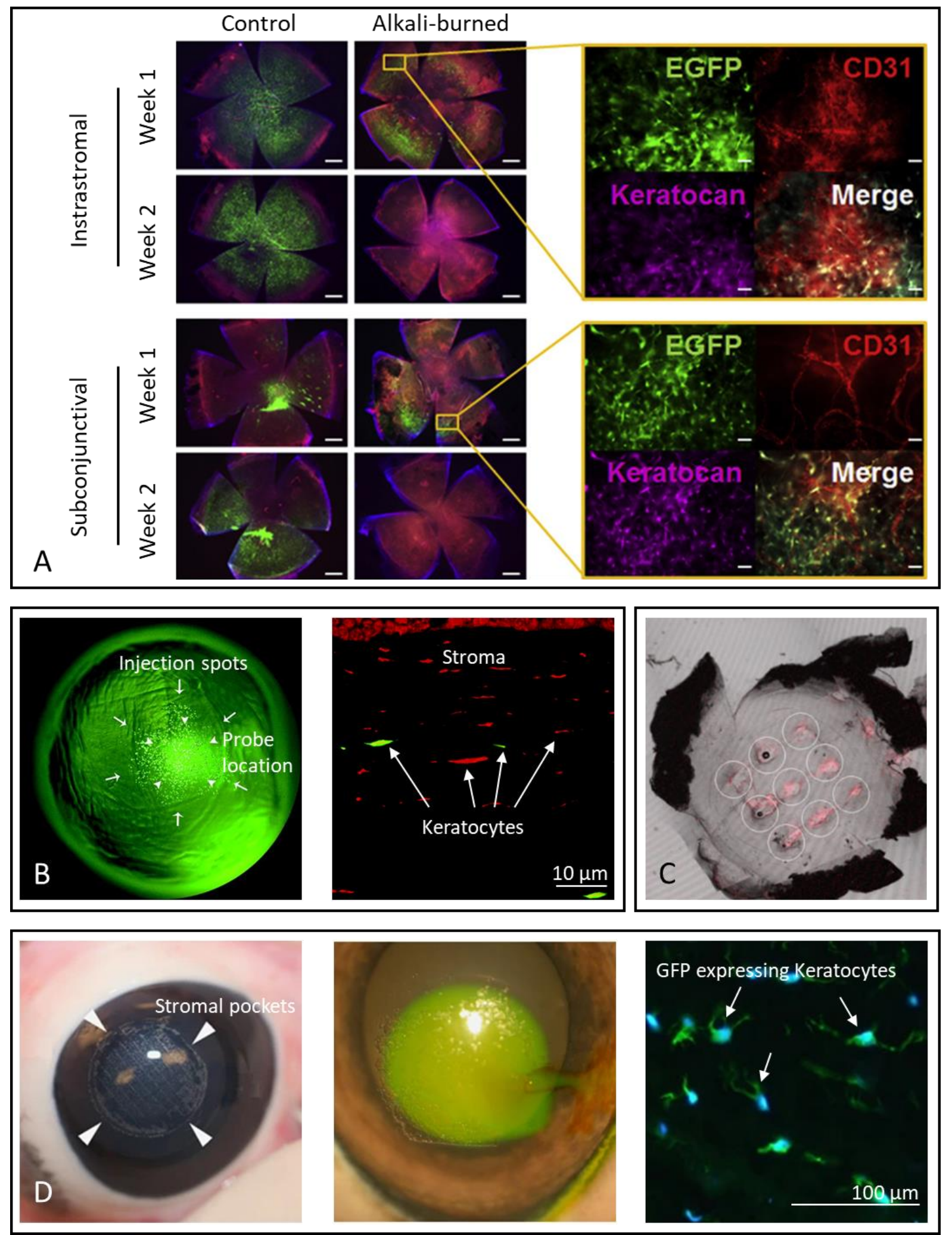

Figure 5. Delivery of biologics to the stroma. (A) Fluorescence images of the cornea following respectively intrastromal and subconjunctival injections of rAAVrh.10 eGFP vectors. In both healthy and damaged mouse corneas eGFP signal was observed in the stroma for a week after treatment. IS and SC injections proved to be equally effective [107]. (B) GFP expression is clearly visible (in the 
corneal section; right panel) after intrastromal injection of naked pDNA and microbubbles followed by ultrasound treatment. Arrows show the injection spot of the pDNA and microbubbles. Arrowheads show the location of the ultrasound probe [116]. (C) Signal of red fluorescently labelled IgG was still visible in the stroma of mice after removal of solvable microneedles indicating successful stromal delivery [119]. (D) Laser-assisted treatment of the stroma is able to create pockets visible as lines running through the cornea (white arrowheads in the left panel). These pockets encompass the whole corneal area, which is clearly visible after fluorescein injection (middle panel). Three days after injecting a lentivirus encoding for GFP, transfected keratocytes are clearly visible, nuclei are stained in blue (right panel) [131]. Adapted from [107,116,119,131].

\section{Delivery of biologics to the corneal endothelium}

Being the deepest layer of the cornea, the endothelium remains difficult to reach after topical administration. Since it is adjacent to the aqueous humor, it is possible to evade many barriers through intracameral injection (i.e. into the aqueous humor) of drugs. The aqueous humor possesses a dynamic barrier due to passive fluid flows $(2.4 \pm 0.6 \mu \mathrm{l} / \mathrm{min})$. A first fluid flow is due to a pressure gradient that moves the aqueous humor through the trabecular meshwork into Schlemm's canal and finally into the draining collector channels. In the second flow (the uveoscleral pathway), the fluid flows through the ciliary muscles into the supraciliary and suprachoroidal spaces and finally leaves the eye through scleral channels and veins [67]. These fluid flows accelerate the clearance after intracameral injection and thus reduce the availability of injected drugs. Another drawback is that the aqueous humor is in contact with other tissues and several reports show that the trabecular meshwork, the iris and even the lens can be transfected after intracameral injection [133-135]. If the endothelial layer is compromised it often leads to corneal blindness, making it an important therapeutic target despite the challenges to reach it.

\section{1. (Bio)chemical methods}

\section{Naked Delivery}

Recently, the company Sylentis has shown promising outcomes and reached clinical trials stage llb (last update 2016 [136]) with topically applied (naked) siRNA targeting the Adrenergic Receptor beta-2 which is involved in glaucoma and intraocular pressure. This receptor is only present in the endothelial layer. Five minutes after instilling siRNA in the eyes of rabbits it could be detected (post-mortem using a complementary fluorescent strand) in the cornea as well as in the ciliary body and the aqueous humor. The effect lasted longer than the standard care anti-glaucoma drugs latanoprost and dorzolamide and reached its maximum potency after 4 days. Interestingly, authors concluded that naked siRNA degrades slower in the aqueous humor than in serum, giving it time to distribute to the 
surrounding tissues [137]. Results from the Ilb trial indicated a lowering of intraocular pressure in open-angle glaucoma patients, without adverse events [136].

Chau et al. described the delivery of (naked) antisense oligonucleotides against Metastasis-Associated Lung Adenocarcinoma Transcript 1 (MALAT1) in C57BL6J mice. MALAT1 is a noncoding nuclear RNA target that is also expressed in the corneal endothelium. They investigated knockdown of MALAT1 and observed a reduced expression of MALAT1 (of 60\%) after both intravitreal and intracameral injection of MALAT1-targeting antisense oligonucleotides [138].

\section{Viral Vectors}

Budenz et al. used recombinant adenoviruses to deliver the reporter gene lacZ to the corneal endothelium and the trabecular meshwork in mice. Injections were performed intracamerally and intravitreally. Transfection of the endothelium was visible in both cases. However, injection into the aqueous humor was favorable as the endothelium of all eyes injected intracamerally showed expression while only 2 out of 3 of the intravitreally injected eyes did. In both cases, the expression did not last more than 14 days [133]. Tsai et al. used the same carrier but looked at the influence of inflammatory responses in a rabbit model. By inducing an inflammatory response by an intravitreal injection of lipopolysaccharides, they observed a drastic increase in eGFP expression in the corneal endothelium as opposed to a normal situation (i.e. without inflammation). When the inflammation stopped, the expression also decreased. By inducing the inflammatory response a second time the expression could be increased again (Figure 6A). As mentioned before, the process behind this observation is still unclear, however, there could be a boost of rAAV-mediated gene expression as DNA repair is stimulated through inflammation and gene expression is promoted by DNA repair [109].

A different approach with viral vectors was investigated in donor tissues. The rationale behind ex vivo transfection of excised corneas is that many donor corneas are discarded before transplantation due to a low endothelial cell count [139]. The ability to transfect the endothelial layer (to induce cell growth) while in a tissue bank storage might increase the quality and availability of tissues. Hudde et al. investigated rAAV and recombinant herpes simplex viruses ( $\mathrm{rHSV}$ ) to deliver the reporter gene lacZ into the corneal endothelium of rabbit and human cornea ex vivo. The vector rAAV showed only $2 \%$ of the endothelial cells transfected in both species. The signal lasted up until 4 weeks, which is also the maximum duration transplants are stored. rHSV showed $5 \%$ of the corneal endothelial cells transfected but had a maximum expression after 1 day, which declined to low levels after a week. rHSV also displayed cytotoxicity, which thus needs to be addressed before being a viable therapeutic option [140]. Lai et al. used an rAAV2 vector with a CMV promotor and saw transfection in $90 \%$ of the endothelial cells which remained stable for up to 2 weeks. They argued that the differences in 
transfection efficiency between their study and the one of Hudde et al. could be attributed to the usage of a growth factor-enriched medium that improved endothelial cell survival [141].

Lentiviruses are interesting for the transfection of endothelial cells as they are capable of transfecting non-dividing cells. These vectors show generally lower immunogenicity and longer expression [142]. Bainbridge et al. used a lentiviral vector to deliver a GFP plasmid through an intracameral injection in C57BI-6J mice. This led to a stable expression of GFP 7 days after treatment across two-thirds of the corneal diameter in the endothelial layer, and being still detectable after 12 weeks (Figure 6B). No inflammatory response was observed with this lentivirus [135]. A similar experiment was performed by Yu et al. in an alkali burn neovascularized rat model using a recombinant adenoviral vector. After intracameral injection, they observed expression of sFlk-1, a receptor capable of binding VEGF and mitigating activation of VEGF receptors, for at least 2 weeks [112].

\section{Physical methods}

\section{Electroporation}

Oshima et al. showed delivering pDNA coding for lacZ to the endothelium was possible using electric pulses $[143,144]$. Naked pDNA was injected into the aqueous humor of adult rats, albeit without transfecting the endothelial cells. By applying electric pulses to the endothelial layer (via a ring-shaped electrode placed on the cornea), the injected pDNA effectively transfected the endothelial cells (Figure $6 C)$. Eight electric pulses of $20 \mathrm{~V}(50 \mathrm{~ms})$ showed successful gene transfection without apparent cell or corneal damage and inflammation. Higher voltage ( $40 \mathrm{~V}$ or higher) led to corneal opacity after 3 days. Interestingly, since the electric pulses were very locally applied, no other tissues showed transfection. However, transfection was predominantly observed in the periphery of the endothelial layer (i.e outside of the visual axis), leaving room for improvement as clear vision in the pupillary zone of the endothelium is most important. Highest expression was seen on days 1 and 3 after injection, indicating the need to repeat the treatment to prolong the effect [144]. Different research groups reported that injecting pDNA intrastromally followed by electroporation did not lead to significant expression in the endothelial layer $[82,83,117]$. Though the Descemet's membrane is not considered as a barrier, it seems pDNA might have difficulties to cross it. Also the application of electric pulses did not seem to sufficiently affect the membrane to allow the passage of pDNA.

\section{Gene Gun}

As outlined above, it is unlikely that gene gun therapy is suitable to deliver biologics in corneal endothelial cells due to its relatively long distance $(\sim 550 \mu \mathrm{m})$ from the cornea [88]. However, Klebe et al. investigated gene gun delivery on these cells in an ovine ex vivo setting by shooting from the 
posterior side (at a distance of $4.5 \mathrm{~cm}$ from the endothelium). By directly targeting the endothelial cells, they found that the endothelial layer became irreversibly damaged. The gold microparticles were able to damage the nuclei thus inducing cell death. The transfection of the remaining living cells was found to be very low $(<0.1 \%)$ confirming that gene gun is not the preferred method for transfecting the corneal endothelium [145].

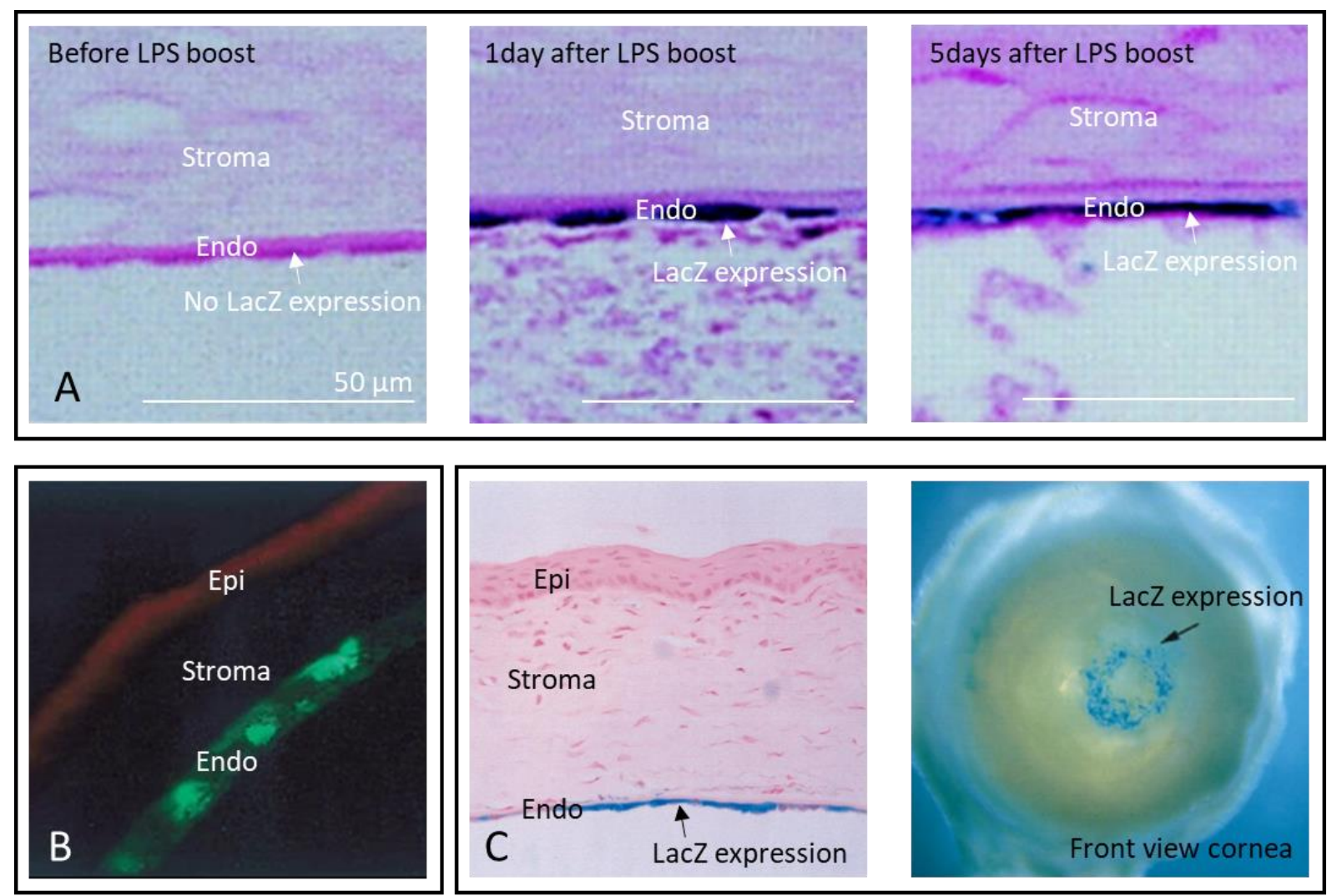

Figure 6. Delivery of biologics to the endothelium. (A) After expression of lacZ was no longer detectable (left panel), administrating LPS led to the reactivation of lacZ expression (middle panel). This expression was at least detectable for 5 days after LPS boost (right panel). In blue lacZ counterstained with X-Gal is visible [109]. (B) Intracameral injection of lentiviruses with pDNA coding for GFP leads to expression in the endothelium up to 6 weeks after treatment [135]. (C) After an intracameral injection of a pDNA coding for the reporter gene lacZ followed by electroporation, a clear expression (in blue) could be seen in the endothelium 3 days after treatment (left panel). The expression in the cornea is clustered around the spot where the pulses were delivered via a ringshaped electrode placed on the cornea (right panel) [144]. Adapted from [109,135,144]. 


\begin{tabular}{|c|c|c|c|c|c|c|c|c|c|c|}
\hline \multicolumn{2}{|c|}{ Bio(chemical) } & Cargo & $\begin{array}{c}\text { Size } \\
\text { Cargo }\end{array}$ & $\begin{array}{c}\text { Size } \\
\text { Carrier }\end{array}$ & Target & Disease & $\begin{array}{c}\text { Delivery } \\
\text { type/administration }\end{array}$ & Primary outcome & Tested in & Reference \\
\hline \multirow{11}{*}{ 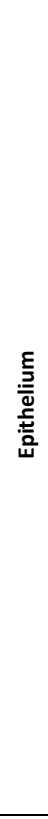 } & \multirow{3}{*}{ Naked delivery } & $\begin{array}{c}\text { Antisense } \\
\text { oligonucleotide }\end{array}$ & $7 \mathrm{kDa}$ & - & $\begin{array}{l}\text { insulin receptor } \\
\text { substrate-1 }\end{array}$ & Keratitis & Topical administration & $\begin{array}{l}\text { The relative area of neovascularization in epithelium } \\
\text { narrowed when treated. }\end{array}$ & Human & $\begin{array}{l}\text { Cursiefen } \\
\text { et al. [55] }\end{array}$ \\
\hline & & SiRNA & $\sim 13 \mathrm{kDa}$ & - & TRPV1 & Dry eye disease & Topical administration & Symptoms of dry eye disease improved with treatment. & Human & $\begin{array}{l}\text { Benitez- } \\
\text { Del-Castillo } \\
\text { et al. [56] }\end{array}$ \\
\hline & & siRNA & $\sim 13 \mathrm{kDa}$ & - & TRPV1 & Dry eye disease & Topical administration & $\begin{array}{l}\text { Reduced symptoms of dry eye disease, especially in } \\
\text { patients suffering from Sjögren's Syndrome. }\end{array}$ & Human & $\begin{array}{c}\text { Gonzales et } \\
\text { al. [136] }\end{array}$ \\
\hline & \multirow{3}{*}{$\begin{array}{l}\text { Cell } \\
\text { Penetrating } \\
\text { Peptides }\end{array}$} & Lissamine & $4 \mathrm{kDa}$ & - & Epithelial cells & POC & Cell penetrating peptide & $\begin{array}{l}\text { Lissamine-conjugated POD was internalized into the } \\
\text { epithelium unlike free lissamine. }\end{array}$ & Mice & $\begin{array}{c}\text { Johnson et } \\
\text { al. [59] }\end{array}$ \\
\hline & & GFP Protein & $32 \mathrm{kDa}$ & - & Epithelial cells & POC & Cell penetrating peptide & $\begin{array}{l}\text { The GFP-POD fusion protein resulted in epithelial uptake } \\
\text { unlike GFP alone. }\end{array}$ & Mice & $\begin{array}{c}\text { Johnson et } \\
\text { al. [60] }\end{array}$ \\
\hline & & SiRNA & $\sim 13 \mathrm{kDa}$ & $107 \mathrm{~nm}$ & $\begin{array}{c}\text { luciferase } \\
\text { reporter gene }\end{array}$ & POC & $\begin{array}{l}\text { Cell penetrating peptide } \\
\text { after CAD treatment }\end{array}$ & $\begin{array}{l}\text { Knockdown of luciferase could be seen up to } 72 \text { hours } \\
\text { after treatment. }\end{array}$ & Mice & $\begin{array}{c}\text { Schiroli et } \\
\text { al. [64] }\end{array}$ \\
\hline & \multirow{2}{*}{$\begin{array}{l}\text { Non-viral } \\
\text { vector }\end{array}$} & siRNA & $\sim 13 \mathrm{kDa}$ & $158 \mathrm{~nm}$ & TGF- $\beta 1$ & Chemical injuries & PEI polyplexes & $\begin{array}{l}\text { Angiogenesis and fibroses could no longer be detected } 21 \\
\text { days after treatment. }\end{array}$ & Mice & $\begin{array}{c}\text { Zahir- } \\
\text { Jouzdani et } \\
\text { al. [66] }\end{array}$ \\
\hline & & siRNA & $\sim 13 \mathrm{kDa}$ & $397 \mathrm{~nm}$ & $\begin{array}{l}\text { luciferase } \\
\text { reporter gene }\end{array}$ & POC & $\begin{array}{c}\text { biodegradable } \\
\text { silicon/lipid nanoparticles } \\
\text { (ProSilic })\end{array}$ & A maximum $41 \%$ knockdown of luciferase at day 11. & Mice & $\begin{array}{c}\text { Baran- } \\
\text { Rachwalska } \\
\text { et al. [69] }\end{array}$ \\
\hline & \multirow{3}{*}{ Viral Vector } & lacZ gene & $3,1 \mathrm{~kb}$ & $\sim 90 \mathrm{~nm}$ & Epithelial cells & POC & Adenovirus type 5 & $\begin{array}{l}\text { The epithelium was not transfected by the vector, } \\
\text { however the conjunctiva was. }\end{array}$ & Rats & $\begin{array}{c}\text { Tsubota et } \\
\text { al. [75] }\end{array}$ \\
\hline & & GFP pDNA & $0.7 \mathrm{~kb}$ & $\sim 175 \mathrm{~nm}$ & Epithelial cells & POC & $\begin{array}{c}\text { Adenovirus } \\
\text { functionalized coated } \\
\text { with chitosan }\end{array}$ & $\begin{array}{l}\text { Functionalizing the adenovirus with chitosan increased its } \\
\text { transfection efficiency. }\end{array}$ & Rats & $\begin{array}{l}\text { Wang et al. } \\
\text { [76] }\end{array}$ \\
\hline & & lacZ gene & $3,1 \mathrm{~kb}$ & $\sim 175 \mathrm{~nm}$ & Epithelial cells & POC & Herpes simplex virus-1 & $\begin{array}{l}\text { On an intact cornea topical administration did not lead to } \\
\text { transfection, however scarring the cornea before } \\
\text { administration did. }\end{array}$ & $\begin{array}{c}\text { Mice \& } \\
\text { Rats }\end{array}$ & $\begin{array}{c}\text { Spencer et } \\
\text { al. [77] }\end{array}$ \\
\hline \multirow{8}{*}{ 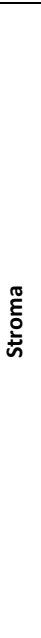 } & \multirow{2}{*}{ Naked delivery } & siRNA & $\sim 13 \mathrm{kDa}$ & - & VEGF-A & Neovascularization & Subconjunctival injection & $\begin{array}{l}\text { VEGF levels were reduced and the neovascularized area } \\
\text { shrunk after treatment. }\end{array}$ & Mice & $\begin{array}{l}\text { Zuo et al. } \\
\text { [94] }\end{array}$ \\
\hline & & siRNA & $\sim 13 \mathrm{kDa}$ & - & VEGF & Neovascularization & Intrastromal injection & Decrease of VEGF levels and neovascularized area. & Mice & $\begin{array}{l}\text { Singh et al. } \\
\text { [95] }\end{array}$ \\
\hline & \multirow{4}{*}{$\begin{array}{l}\text { Non-viral } \\
\text { vectors }\end{array}$} & siRNA & $\sim 13 \mathrm{kDa}$ & $\begin{array}{c}\text { Not } \\
\text { mentioned }\end{array}$ & $\begin{array}{l}\text { VEGFA, VEGFR1 } \\
\text { and VEGFR2 }\end{array}$ & angiogenesis & $\begin{array}{c}\text { subconjunctival and } \\
\text { systemic administration } \\
\text { of TargeTran }\end{array}$ & $\begin{array}{l}\text { Subconjunctival treatment was more effective in new } \\
\text { vessel inhibition. }\end{array}$ & Mice & $\begin{array}{c}\text { Kimet al. } \\
{[96]}\end{array}$ \\
\hline & & GFP pDNA & $0.7 \mathrm{~kb}$ & $\begin{array}{c}\text { Not } \\
\text { mentioned }\end{array}$ & Keratocytes & POC & $\begin{array}{l}\text { Topical administration of } \\
\text { PEI-polyplexes after } \\
\text { epithelium removal } \\
\end{array}$ & $\begin{array}{l}\text { Keratocytes were successfully transfected in the anterior } \\
\text { and middle part of stroma. }\end{array}$ & Mice & $\begin{array}{l}\text { Rodier et } \\
\text { al. [100] }\end{array}$ \\
\hline & & $\begin{array}{c}\text { monoclonal } \\
\text { antibody } \\
\text { (bevacizumab) }\end{array}$ & $149 \mathrm{kDa}$ & $300 \mathrm{~nm}$ & VEGF & Neovascularization & $\begin{array}{l}\text { (PEG)Albumin } \\
\text { nanoparticles }\end{array}$ & $\begin{array}{l}\text { Albumin nanoparticles and PEG-albumin nanoparticles } \\
\text { decreased the neovascularized area by } 61 \% \text { and } 38 \% \text {, } \\
\text { respectively. }\end{array}$ & Rats & $\begin{array}{c}\text { Luis de } \\
\text { Redín et al. } \\
\text { [101] }\end{array}$ \\
\hline & & $\begin{array}{c}\text { monoclonal } \\
\text { antibody } \\
\text { (bevacizumab) }\end{array}$ & $149 \mathrm{kDa}$ & $\sim 140 \mathrm{~nm}$ & VEGF & Neovascularization & $\begin{array}{c}\text { subconjunctivally } \\
\text { injected mesoporous } \\
\text { silica nanoparticles } \\
\end{array}$ & $\begin{array}{l}\text { Free and encapsulated bevacizumab led to a reduction of } \\
\text { vascular length around } 80 \% \text { and } 90 \% \text { respectively at day } \\
14 .\end{array}$ & Mice & $\begin{array}{l}\text { Sun et al. } \\
\text { [104] }\end{array}$ \\
\hline & \multirow[t]{2}{*}{ Viral Vectors } & GFP pDNA & $0.7 \mathrm{~kb}$ & $\sim 90 \mathrm{~nm}$ & Keratocytes & POC & $\begin{array}{l}\text { Intrastromally injected } \\
\text { adenovirus }\end{array}$ & $\begin{array}{l}\text { Delivering through intrastromal injected adenoviruses led } \\
\text { to more keratocytes transfection compared to naked } \\
\text { pDNA. }\end{array}$ & Mice & $\begin{array}{l}\text { Carlson et } \\
\text { al. [105] }\end{array}$ \\
\hline & & GFP pDNA & $0.7 \mathrm{~kb}$ & $\sim 22 \mathrm{~nm}$ & Keratocytes & $\mathrm{POC}$ & $\begin{array}{l}\text { Topical and intrastromal } \\
\text { administered rAAVs }\end{array}$ & $\begin{array}{l}\text { Only after removal of the epithelium serotypes rAAVrh.10 } \\
\text { and rAAVrh.39 transfected successfully. }\end{array}$ & Mice & $\begin{array}{l}\text { Lu et al. } \\
{[106]}\end{array}$ \\
\hline
\end{tabular}




\begin{tabular}{|c|c|c|c|c|c|c|c|c|c|c|}
\hline & & MicroRNA & $\begin{array}{c}\text { Not } \\
\text { mentioned }\end{array}$ & $\sim 22 \mathrm{~nm}$ & $\begin{array}{l}\text { hey2, gjc1, } \\
\text { rasip1, and amot } \\
\text { genes }\end{array}$ & Neovascularization & $\begin{array}{l}\text { Subconjunctival and } \\
\text { intrastromal } \\
\text { administered rAAV }\end{array}$ & $\begin{array}{l}\text { Both administration routes resulted in a significant } \\
\text { decrease of vascularized areas. }\end{array}$ & Mice & $\begin{array}{l}\text { Luet al. } \\
\text { [107] }\end{array}$ \\
\hline & & GFP pDNA & $0.7 \mathrm{~kb}$ & $\sim 22 \mathrm{~nm}$ & Keratocytes & POC & $\begin{array}{l}\text { Intrastromally injected } \\
\text { AAV }\end{array}$ & $\begin{array}{l}\text { GFP expression remained for } 17 \text { months. Administrating } \\
\text { an LPS or PBS injection led to a temporary boost in } \\
\text { expression likely due to an inflammatory response to the } \\
\text { injection. }\end{array}$ & Mice & $\begin{array}{l}\text { Hippert et } \\
\text { al. [108] }\end{array}$ \\
\hline & & GFP pDNA & $0.7 \mathrm{~kb}$ & $\sim 22 \mathrm{~nm}$ & Stromal cells & POC & $\begin{array}{l}\text { Intrastromally injected } \\
\text { AAV using micro sized } \\
\text { needles }\end{array}$ & $\begin{array}{l}\text { Injections with micro sized needles were more accurate } \\
\text { and led to less anterior chamber penetration and leakage. }\end{array}$ & Rabbits & $\begin{array}{l}\text { Gilger et al. } \\
\quad[110]\end{array}$ \\
\hline & & Smad7 gene & $1.3 \mathrm{~kb}$ & $\sim 22 \mathrm{~nm}$ & Stromal cells & $\begin{array}{l}\text { Corneal haze } \\
\text { formation }\end{array}$ & topical delivery of AAV5 & Treated eyes showed relatively less cloudiness and haze. & Rabbits & $\begin{array}{l}\text { Gupta et } \\
\text { al. [111] }\end{array}$ \\
\hline & & sFlk-1 gene & $\begin{array}{c}\text { Not } \\
\text { mentioned }\end{array}$ & $\sim 90 \mathrm{~nm}$ & Stromal cells & Neovascularization & $\begin{array}{l}\text { Injection of rAV into } \\
\text { aqueous humor }\end{array}$ & 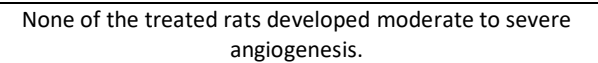 & Rats & $\begin{array}{l}\text { Yuet al. } \\
\text { [112] }\end{array}$ \\
\hline \multirow{7}{*}{ 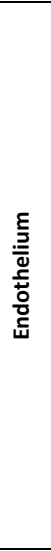 } & \multirow{2}{*}{ Naked delivery } & siRNA & $\sim 13 \mathrm{kDa}$ & - & $\begin{array}{c}\text { Adrenergic } \\
\text { Receptor beta-2 } \\
\end{array}$ & $\begin{array}{c}\text { glaucoma and } \\
\text { intraocular pressure }\end{array}$ & Naked delivery & $\begin{array}{l}\text { Results indicated a lowering of intraocular pressure in } \\
\text { open-angle glaucoma patients, without adverse events. }\end{array}$ & Rabbits & $\begin{array}{c}\text { Martínez et } \\
\text { al. [137] }\end{array}$ \\
\hline & & $\begin{array}{c}\text { antisense } \\
\text { oligonucleotide }\end{array}$ & $7 \mathrm{kDa}$ & - & MALAT1 & POC & $\begin{array}{c}\text { Intravitreal and } \\
\text { intracameral injections }\end{array}$ & $\begin{array}{l}\text { A reduced expression of MALAT1 of } 60 \% \text { after both } \\
\text { intravitreal and intracameral injection could be observed. }\end{array}$ & Mice & $\begin{array}{c}\text { Chau et al. } \\
{[138]}\end{array}$ \\
\hline & \multirow{5}{*}{ Viral Vectors } & GFP pDNA & $0.7 \mathrm{~kb}$ & $\sim 90 \mathrm{~nm}$ & Endothelial cells & POC & $\begin{array}{l}\text { Intracamerally injected } \\
\text { rAV }\end{array}$ & $\begin{array}{l}\text { GFP expression after transfection could be temporarily be } \\
\text { increased by intravitreally injecting LPS. After the } \\
\text { inflammation subsided expression also decreased. This } \\
\text { boost was repeatable a second time. }\end{array}$ & Rabbit & $\begin{array}{l}\text { Tsai et al. } \\
{[109]}\end{array}$ \\
\hline & & lacZ gene & $3,1 \mathrm{~kb}$ & $\sim 90 \mathrm{~nm}$ & Endothelial cells & POC & $\begin{array}{l}\text { rAV after Intracamerally } \\
\text { or intravitreally injected }\end{array}$ & $\begin{array}{l}\text { Both administration routes led to expression however } \\
\text { injections into the aqueous humor were favorable as } \\
\text { more mice showed expression. }\end{array}$ & Mice & $\begin{array}{l}\text { Budenz et } \\
\text { al. [133] }\end{array}$ \\
\hline & & lacZ gene & $3,1 \mathrm{~kb}$ & $\begin{array}{l}\sim 22 \mathrm{~nm} \& \\
200 \mathrm{~nm}\end{array}$ & Endothelial cells & POC & $\begin{array}{l}\text { rAAV and rHSV while in } \\
\text { storage medium }\end{array}$ & $\begin{array}{l}\text { Only } 2 \% \text { of the endothelial cells were transfected in both } \\
\text { species which lasted for } 4 \text { weeks with rAAV compared to } \\
5 \% \text { transfection for a week using rHSV. }\end{array}$ & $\begin{array}{l}\text { Ex vivo } \\
\text { (Rabbit \& } \\
\text { human) } \\
\end{array}$ & $\begin{array}{l}\text { Hudde et } \\
\text { al. [140] }\end{array}$ \\
\hline & & GFP pDNA & $0.7 \mathrm{~kb}$ & $\sim 22 \mathrm{~nm}$ & Endothelial cells & POC & $\begin{array}{l}\text { rAAV2 onto ex vivo } \\
\text { endothelial layer }\end{array}$ & $\begin{array}{l}\text { Transfection levels of } 90 \% \text { for two weeks could be } \\
\text { achieved using an rAAV2 vector. }\end{array}$ & $\begin{array}{l}\text { Ex vivo } \\
\text { (human) }\end{array}$ & $\begin{array}{l}\text { Lai et al. } \\
{[141]}\end{array}$ \\
\hline & & GFP pDNA & $0.7 \mathrm{~kb}$ & $\sim 90 \mathrm{~nm}$ & Endothelial cells & $\mathrm{POC}$ & $\begin{array}{c}\text { Lentivirus with } \\
\text { intracameral injection }\end{array}$ & $\begin{array}{l}\text { Expression of GFP across most of the corneal diameter } \\
\text { could be achieved which lasted at least for } 12 \text { weeks. }\end{array}$ & Mice & $\begin{array}{l}\text { Bainbridge } \\
\text { et al. [135] }\end{array}$ \\
\hline
\end{tabular}




\begin{tabular}{|c|c|c|c|c|c|c|c|c|c|c|}
\hline \multicolumn{2}{|r|}{ Physical } & Cargo & $\begin{array}{l}\text { Size } \\
\text { Cargo }\end{array}$ & $\begin{array}{c}\text { Size } \\
\text { Carrier }\end{array}$ & Target & Disease & $\begin{array}{c}\text { Delivery } \\
\text { type/administration }\end{array}$ & Primary outcome & Tested in & Reference \\
\hline \multirow{5}{*}{ 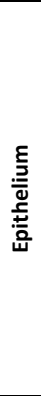 } & Electroporation & $\begin{array}{l}\text { luciferase } \\
\text { pDNA }\end{array}$ & $5,8 \mathrm{~kb}$ & - & Epithelial cells & POC & $\begin{array}{l}\text { Electroporation after } \\
\text { subconjunctival or } \\
\text { intrastromal injection }\end{array}$ & $\begin{array}{l}\text { Using a subconjunctival injection led to a higher } \\
\text { expression but declined faster compared to an } \\
\text { intrastromal injection. }\end{array}$ & Mice & $\begin{array}{l}\text { Blair-Parks } \\
\text { et al. [82] }\end{array}$ \\
\hline & \multirow{4}{*}{ Gene Gun } & GFP pDNA & $0.7 \mathrm{~kb}$ & $2.6 \mu \mathrm{m}$ & Epithelial cells & POC & Gene gun & $\begin{array}{c}\text { Expression was only present around the gold beads. } \\
\text { Adjusting gene gun pressure allowed to target different } \\
\text { epithelial layers. }\end{array}$ & Rabbits & $\begin{array}{c}\text { Tanelian et } \\
\text { al. [85] }\end{array}$ \\
\hline & & $\begin{array}{l}\text { IL-10 and } \\
\text { luciferase } \\
\text { pDNA }\end{array}$ & $\begin{array}{c}\text { Not } \\
\text { mentioned }\end{array}$ & $\begin{array}{l}0.6 \& 1.6 \\
2.6 \mu \mathrm{m}\end{array}$ & Epithelial cells & POC & Gene gun & $\begin{array}{l}\text { Adjusting distance and pressure of the gene gun led to IL- } \\
10 \text { and luciferase expression while minimizing side } \\
\text { effects. }\end{array}$ & Mice & $\begin{array}{l}\text { Zhang et al. } \\
\quad[86]\end{array}$ \\
\hline & & $\begin{array}{l}\text { IL-4 and IL-10 } \\
\text { pDNA }\end{array}$ & $\begin{array}{c}\text { Not } \\
\text { mentioned }\end{array}$ & $\begin{array}{l}0.6 \& 1.6 \\
2.6 \mu \mathrm{m}\end{array}$ & Epithelial cells & $\begin{array}{c}\text { herpetic stromal } \\
\text { keratitis }\end{array}$ & Gene gun & $\begin{array}{l}\text { IL-10 and IL-4 pDNA could successfully delivered and led } \\
\text { to increased IL-10 and IL-4 concentrations. }\end{array}$ & Mice & $\begin{array}{c}\text { Bauer et al. } \\
{[87]}\end{array}$ \\
\hline & & $\begin{array}{l}\text { K12 promoter- } \\
\beta \text {-gal DNA }\end{array}$ & $2,5 \mathrm{~kb}$ & $\begin{array}{l}0.6 \& 1.6 \\
2.6 \mu \mathrm{m}\end{array}$ & Epithelial cells & Promotor identification & Gene gun & $\begin{array}{l}\text { Expression was visible in corneal epithelium but not } \\
\text { conjunctiva. Indicating K12 was located in the epithelium. }\end{array}$ & Rabbits & $\begin{array}{l}\text { Shiraishi et } \\
\text { al. [88] }\end{array}$ \\
\hline \multirow{6}{*}{ 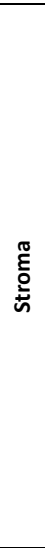 } & Sonoporation & GFP pDNA & $0.7 \mathrm{~kb}$ & - & Keratocytes & POC & Sonoporation & $\begin{array}{l}\text { The transfected cells displayed increasing GFP expression } \\
\text { for } 8 \text { days which slowly decreased and disappeared } \\
\text { completely } 30 \text { days after treatment. }\end{array}$ & Rabbits & $\begin{array}{c}\text { Sonoda et } \\
\text { al. [116] }\end{array}$ \\
\hline & \multirow[b]{2}{*}{ Electroporation } & $\begin{array}{l}\text { luciferase } \\
\text { pDNA }\end{array}$ & $5,8 \mathrm{~kb}$ & - & Keratocytes & POC & $\begin{array}{l}\text { Electroporation after } \\
\text { intracorneal injection }\end{array}$ & $\begin{array}{c}\text { Luciferase expression could successfully be detected } 7 \\
\text { days after the treatment. }\end{array}$ & Mice & $\begin{array}{l}\text { Blair-Parks } \\
\text { et al. [82] }\end{array}$ \\
\hline & & GFP pDNA & $0.7 \mathrm{~kb}$ & - & Keratocytes & POC & Electroporation & $\begin{array}{l}\text { Using } 20 \mathrm{~V} \text { pulses }(50 \mathrm{~ms}) \text { for GFP pDNA delivery led to } \\
\text { GFP expression without apparent damage. } 40 \mathrm{~V} \text { pulses led } \\
\text { to neovascularization. }\end{array}$ & Rats & $\begin{array}{c}\text { Oshima et } \\
\text { al. [117] }\end{array}$ \\
\hline & \multirow[b]{2}{*}{ Microneedles } & $\begin{array}{c}\text { monoclonal } \\
\text { antibody } \\
\text { (bevacizumab) }\end{array}$ & $149 \mathrm{kDa}$ & - & VEGF & Neovascularization & Coated microneedles & $\begin{array}{l}\text { Microneedles and traditional injection led to a similar } \\
\text { reduction of neovascularization. However only a } 550 \\
\text { times lower dose was needed for the microneedles. }\end{array}$ & Rabbits & $\begin{array}{l}\text { Kim et al. } \\
{[118]}\end{array}$ \\
\hline & & $\begin{array}{l}\text { monoclonal } \\
\text { antibody } \\
\text { (DC101) }\end{array}$ & $150 \mathrm{kDa}$ & - & VEGFR2 & Neovascularization & $\begin{array}{l}\text { Microneedles with fast } \\
\text { dissolving diclofenac core } \\
\text { and DC101 loaded slow } \\
\text { release outer shell }\end{array}$ & $\begin{array}{l}\text { Treatment led to a vascularized area of only } 0.16 \mathrm{~mm}^{2} \\
\text { while diclofenac only and DC101 only resulted in a } \\
\text { vascularized area of } 0.63 \mathrm{~mm}^{2} \text { and } 0.52 \mathrm{~mm}^{2} \text { respectively. }\end{array}$ & Mice & $\begin{array}{l}\text { Than et al. } \\
\text { [119] }\end{array}$ \\
\hline & $\begin{array}{l}\text { Light based } \\
\text { delivery }\end{array}$ & GFP pDNA & $0.7 \mathrm{~kb}$ & - & Keratocytes & POC & $\begin{array}{l}\text { Laser created pocket } \\
\text { followed by an injection } \\
\text { with lentiviral vector }\end{array}$ & $\begin{array}{l}\text { Injecting lentivirus vectors expressing GFP in through light } \\
\text { based created pockets led to a transduction of } 90 \% \\
\text { surrounding the pocket. }\end{array}$ & $\begin{array}{c}\text { Ex vivo } \\
\text { (porcine) }\end{array}$ & $\begin{array}{l}\text { Bemelmans } \\
\text { et al. [131] }\end{array}$ \\
\hline \multirow{3}{*}{ 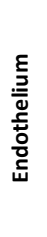 } & \multirow{2}{*}{ Electroporation } & tPA DNA & $1,7 \mathrm{~kb}$ & - & $\begin{array}{l}\text { Endothelial } \\
\text { cells }\end{array}$ & $\begin{array}{l}\text { Intracameral Fibrin } \\
\text { Formation }\end{array}$ & $\begin{array}{c}\text { Electroporation after } \\
\text { injection into the anterior } \\
\text { chamber }\end{array}$ & $\begin{array}{l}\text { Active tPA was clearly present for } 4 \text { days after treatment } \\
\text { lowering corneal opacity. }\end{array}$ & Rats & $\begin{array}{l}\text { Sakamoto } \\
\text { et al. [143] }\end{array}$ \\
\hline & & lacZ pDNA & $3,1 \mathrm{~kb}$ & - & $\begin{array}{l}\text { Endothelial } \\
\text { cells }\end{array}$ & POC & $\begin{array}{l}\text { Electroporation after } \\
\text { injection of naked pDNA } \\
\text { into aqueous humor } \\
\end{array}$ & $\begin{array}{l}20 \mathrm{~V}(50 \mathrm{~ms}) \text { pulses showed successful gene transfection } \\
\text { without apparent damage. } 40 \mathrm{~V} \text { or higher led to corneal } \\
\text { opacity after } 3 \text { days. }\end{array}$ & Rats & $\begin{array}{c}\text { Oshima et } \\
\text { al. [144] }\end{array}$ \\
\hline & Gene Gun & lacZ pDNA & $3,1 \mathrm{~kb}$ & $\begin{array}{c}\text { Not } \\
\text { mentioned }\end{array}$ & $\begin{array}{l}\text { Endothelial } \\
\text { cells }\end{array}$ & POC & Gene gun & $\begin{array}{l}\text { Directly targeting the endothelial led to irreversibly } \\
\text { damaging the endothelial cells. }\end{array}$ & $\begin{array}{l}\text { Ex vivo } \\
\text { (Ovine) }\end{array}$ & $\begin{array}{l}\text { Klebe et al. } \\
\text { [145] }\end{array}$ \\
\hline
\end{tabular}

Table 1. Overview of the delivery of biologics into different layers of the cornea. POC = Proof of concept; TRPV1 = transient receptor potential cation channel subfamily V member 1; MALAT1 = Metastasis-Associated Lung Adenocarcinoma Transcript 1; rAAV = Recombinant adeno-associated viruses; AAV = Adeno-associated viruses; $r A V=$ Recombinant adenovirus; $r H S V=$ recombinant herpes simplex viruses. 


\section{Discussion}

As described above, in last decades many research efforts have been undertaken to deliver biologics (especially nucleic acids) in the cornea, with varying degrees of success (Table 1). However, besides the off label use of bevacizumab against corneal neovascularization, today biologics for corneal treatment could not reach the market. Though, at first glance, the structure and location of the cornea might allow easy delivery of biologics, it consists of many complex barriers. Original and innovative methods are therefore needed to improve the crossing of the barriers and allow efficient delivery of biologics.

Clearly, the simplest way to deliver biologics in the cornea is through administering 'naked' biologics. Also, as no other foreign materials are used it is also considered to be most safe. However, delivering naked biologics is mostly inefficient as their capacity to cross the biological barriers is rather low. To overcome these barriers, non-viral carriers are promising as several examples showed improved transfection of corneal cells when compared to naked delivery. Important to note is that non-viral carriers for biologics become more and more approved by health agencies, though for targets different from the eye. This is illustrated with the approval of Onpattro, the first lipid based non-viral carrier loaded with siRNA, which is intravenously injected to treat polyneuropathy of hereditary transthyretinmediated amyloidosis [146]. Attractive as well is the possibility to modulate the physico-chemical properties of non-viral carriers, this e.g. to prolong their residence time at the surface of the eye (like through surface functionalization with chitosan $[78,79])$. Besides corneal barriers, which still remain difficult to cross with non-viral carriers, a strong challenge remains in the capacity to bypass intracellular barriers, like the endo-lysosomal compartment and avoid degradation of the biological cargo. This has been extensively studied using carriers that contain fusogenic compounds (like DOPE and penetrating peptides) or cationic amphiphilic molecules like chloroquine which has been also studied in the context of corneal drug delivery [64]. Despite the flexibility and versatility non-viral carriers can offer, short-term transfections are often observed, which suggests more frequent injections, reduced compliance and safety. In contrast, viral vectors (like AAV and herpes virus) can provide more durable effects lasting for months for which, however, concerns about immunogenicity and toxicity remain [147]. To obtain the best of both worlds and thus taking advantages of both viral vectors and non-viral carriers, it could be attractive to functionalize viruses with targeting or mucoadhesive compounds to increase their residence time after topical application, as reported by Wang et al. with chitosan-modified adenoviruses [76].

While much work remains to be done, physical methods might become promising to deliver biologics in the cornea. For instance, with gene gun, it is possible to precisely deliver cargos without affecting 
neighboring tissues. Gene gun is, however, only usable for targeting superficial tissues such as the corneal epithelium. As gene gun allows to overcome both superficial extracellular barriers of the cornea (tear film, mucus layer) and intracellular barriers (through direct delivery in the cytosol), it remains attractive. However, it is still debated whether or not gold particles are completely safe to use [148]. Therefore, replacing gold particles with biodegradable particles could be a promising solution as reported for transdermal drug delivery $[149,150]$. Also sonoporation allows to deliver biologics directly into the cytosol of cells. However, depending on the experimental settings, applying ultrasound might generate heat [113] that might damage the cornea. Indeed, heating up collagen fibers in the stroma may cause an immediate opacification that reverts only after a few weeks to months[151]. This risk also has to be considered when exploring light- and electroporation based methods for delivering biologics in the cornea.

Clearly, most of the biologics investigated for corneal delivery are nucleic acids (like siRNA and pDNA) while only few groups focus on corneal delivery of proteins (like antibodies), which remains a huge challenge. Proteins do not easily cross corneal barriers [152] while they are at risk of degradation [152]. Some groups explored nanocarriers [101,104] and microneedles [118] for the corneal delivery of bevacizumab and DC101 in the treatment of corneal neovascularization. Microneedles became an interesting alternative to conventional injections as they might allow larger molecules (and even adenoviruses [153]) to be delivered directly into the region of interest. It is suggested that the local dissolution of solid (coated) needles leads to much higher localized concentrations than when using regular injections, thus a lower dosage might be sufficient. Also, mesoporous silica nanoparticles slowly releasing proteins are also attractive as it decreases the amount of injections needed in a treatment schedule [104].

It is also important not to lose sight of patient comfort. In all the above studies, most of the observed effects last a couple of weeks, at most, which means multiple injections would be necessary, thus lowering patient compliance. Besides, invasive treatments by injection can lead to infections adding an extra risk [154]. While topical administration would be most ideal, it still seems today that subconjunctival or intrastromal injections are the most efficient ways to administer drugs to the cornea. However, recently, quantum dots have been shown to reach the stroma after topical administration and exert an antibiotic activity against Staphylococcus aureus [155]; the authors suggested the investigated quantum dots disrupt epithelial tight junctions $[155,156]$. Such rather unexpected observations might stimulate the drug delivery community to find approaches which make topical delivery biologics into the cornea true. 


\section{Conclusion}

This review summarized various strategies to deliver biologics to the cornea. Examples with varying success in transfecting the different layers of the cornea are reported. However, to us many studies remain rather observational: while the extent of delivery of biological molecules is reported (using ex vivo or in vivo models), the biological barriers that are limiting the delivery process are mostly not investigated in detail and remain thus largely unclear. Indeed, it undoubtedly appears that fundamental studies to obtain much better insights into interactions between biologics and the corneal layers are highly needed. Moreover, in animal studies showing successful delivery of biologics in the cornea, details on the distribution, degradation and clearance of biologics is often lacking. It is also important to mention that efficient approaches to deliver biologics in the cornea might open new perspectives as well for optimizing corneal storage and therefore improving the quality of corneal grafts. Though there is still a long way to go, research on the corneal delivery of biologics holds great promise and comprehensive studies will certainly allow to bridge the gap towards clinical translation. 


\section{References}

[1] WHO, Global data on visual impairments 2010, (2012). http://www.who.int/blindness/GLOBALDATAFINALforweb.pdf (accessed August 15, 2017).

[2] M. Sacchetti, A. Lambiase, Diagnosis and management of neurotrophic keratitis., Clin. Ophthalmol. 8 (2014) 571-9. https://doi.org/10.2147/OPTH.S45921.

[3] Y. Bu, K.C. Shih, S.S. Kwok, Y.K. Chan, A.C.-Y. Lo, T.C.Y. Chan, V. Jhanji, L. Tong, Experimental modeling of cornea wound healing in diabetes: clinical applications and beyond, BMJ Open Diabetes Res. Care. 7 (2019). https://doi.org/10.1136/BMJDRC-2019-000779.

[4] S.R. Nyman, M.A. Gosney, C.R. Victor, Emotional well-being in people with sight loss, Br. J. Vis. Impair. 28 (2010) 175-203. https://doi.org/10.1177/0264619610374171.

[5] V. Tadić, A.O. Robertson, M. Cortina-Borja, J.S. Rahi, Child Vision Patient-Reported Outcome Measures Group, An Age- and Stage-Appropriate Patient-Reported Outcome Measure of Vision-Related Quality of Life of Children and Young People with Visual Impairment., Ophthalmology. 127 (2020) 249-260. https://doi.org/10.1016/j.ophtha.2019.08.033.

[6] P. Gain, R. Jullienne, Z. He, M. Aldossary, S. Acquart, F. Cognasse, G. Thuret, Global Survey of Corneal Transplantation and Eye Banking, JAMA Ophthalmol. 134 (2016) 167. https://doi.org/10.1001/jamaophthalmol.2015.4776.

[7] K.H. Wong, K.W. Kam, L.J. Chen, A.L. Young, Corneal blindness and current major treatment concern-graft scarcity, Int. J. Ophthalmol. 10 (2017) 1154. https://doi.org/10.18240/IJO.2017.07.21.

[8] B. Zhang, Q. Xue, J. Li, L. Ma, Y. Yao, H. Ye, Z. Cui, H. Yang, 3D bioprinting for artificial cornea: Challenges and perspectives, Med. Eng. Phys. 71 (2019) 68-78.

https://doi.org/10.1016/J.MEDENGPHY.2019.05.002.

[9] L. Lin, X. Jin, The development of tissue engineering corneal scaffold: which one the history will choose?, Ann. Eye Sci. 3 (2018) 6-6. https://doi.org/10.21037/aes.2018.01.01.

[10] A.C. Anselmo, Y. Gokarn, S. Mitragotri, Non-invasive delivery strategies for biologics., Nat. Rev. Drug Discov. 18 (2019) 19-40. https://doi.org/10.1038/nrd.2018.183.

[11] J.S. Weiss, H.U. Møller, W. Lisch, S. Kinoshita, A.J. Aldave, M.W. Belin, T. Kivelä, M. Busin, F.L. Munier, B. Seitz, J. Sutphin, C. Bredrup, M.J. Mannis, C.J. Rapuano, G. Van Rij, E.K. Kim, G.K. Klintworth, The IC3D classification of the corneal dystrophies., Cornea. 27 Suppl 2 (2008) S183. https://doi.org/10.1097/ICO.0b013e31817780fb.

[12] V. Oliver, K. van Bysterveldt, M. Cadzow, B. Steger, V. Romano, D. Markie, A. Hewitt, D. Mackey, C. Willoughby, T. Sherwin, P. Crosier, C. McGhee, A. Vincent, A COL17A1 SpliceAltering Mutation Is Prevalent in Inherited Recurrent Corneal Erosions, Ophthalmology. 123 (2016). https://doi.org/10.1016/J.OPHTHA.2015.12.008.

[13] M.E. Fini, B.M. Stramer, How the cornea heals: cornea-specific repair mechanisms affecting surgical outcomes, Cornea. 24 (2005). https://doi.org/10.1097/01.ICO.0000178743.06340.2C.

[14] R.R. Mohan, Corneal transparency restoration by gene therapy, Acta Ophthalmol. 97 (2019) j.1755-3768.2019.8248. https://doi.org/10.1111/j.1755-3768.2019.8248.

[15] M.D.P. Willcox, P. Argüeso, G.A. Georgiev, J.M. Holopainen, G.W. Laurie, T.J. Millar, E.B. Papas, J.P. Rolland, T.A. Schmidt, U. Stahl, T. Suarez, L.N. Subbaraman, O.Ö. Uçakhan, L. Jones, TFOS DEWS II Tear Film Report, Ocul. Surf. 15 (2017) 366-403. https://doi.org/10.1016/J.JTOS.2017.03.006.

[16] S. Mishima, A. Gasset, S.D. Klyce, J.L. Baum, Determination of Tear Volume and Tear Flow, Invest. Ophthalmol. Vis. Sci. 5 (1966) 264-276. https://iovs.arvojournals.org/article.aspx?articleid=2203634 (accessed June 24, 2020).

[17] S.-C. Chang, V.H.L. Lee, Nasal and Conjunctival Contributions to the Systemic Absorption of Topical Timolol in the Pigmented Rabbit: Implications in the Design of Strategies to Maximize the Ratio of Ocular to Systemic Absorption, J. Ocul. Pharmacol. Ther. 3 (1987) 159-169. https://doi.org/10.1089/jop.1987.3.159.

[18] A. Urtti, H. Rouhiainen, T. Kaila, V. Saano, Controlled Ocular Timolol Delivery: Systemic 
Absorption and Intraocular Pressure Effects in Humans, Pharm. Res. 11 (1994) 1278-1282. https://doi.org/10.1023/A:1018938310628.

[19] L. Cwiklik, Tear film lipid layer: A molecular level view, Biochim. Biophys. Acta - Biomembr. 1858 (2016) 2421-2430. https://doi.org/10.1016/J.BBAMEM.2016.02.020.

[20] L. Sebbag, L.M. Moody, J.P. Mochel, Albumin Levels in Tear Film Modulate the Bioavailability of Medically-Relevant Topical Drugs., Front. Pharmacol. 10 (2019) 1560. https://doi.org/10.3389/fphar.2019.01560.

[21] N.J. Van Haeringen, Clinical biochemistry of tears, Surv. Ophthalmol. 26 (1981) 84-96. https://doi.org/10.1016/0039-6257(81)90145-4.

[22] Y. Danjo, L.D. Hazlett, I.K. Gipson, C57BL/6 Mice Lacking Muc1 Show No Ocular Surface Phenotype, Invest. Ophthalmol. Vis. Sci. 41 (2000) 4080-4084. https://iovs.arvojournals.org/article.aspx?articleid=2162707 (accessed June 25, 2020).

[23] R. Kardon, R.E. Price, J. Julian, E. Lagow, S.C. Tseng, S.J. Gendler, D.D. Carson, Bacterial conjunctivitis in Muc1 null mice., Invest. Ophthalmol. Vis. Sci. 40 (1999) 1328-35. http://www.ncbi.nlm.nih.gov/pubmed/10359313 (accessed June 25, 2020).

[24] T.D. Blalock, S.J. Spurr-Michaud, A.S. Tisdale, S.R. Heimer, M.S. Gilmore, V. Ramesh, I.K. Gipson, Functions of MUC16 in Corneal Epithelial Cells, Investig. Opthalmology Vis. Sci. 48 (2007) 4509. https://doi.org/10.1167/iovs.07-0430.

[25] P. Argüeso, A. Tisdale, S. Spurr-Michaud, M. Sumiyoshi, I.K. Gipson, Mucin characteristics of human corneal-limbal epithelial cells that exclude the rose bengal anionic dye., Invest. Ophthalmol. Vis. Sci. 47 (2006) 113-9. https://doi.org/10.1167/iovs.05-0735.

[26] F. Mantelli, P. Argüeso, Functions of ocular surface mucins in health and disease., Curr. Opin. Allergy Clin. Immunol. 8 (2008) 477-83. https://doi.org/10.1097/ACl.0b013e32830e6b04.

[27] M. Ruponen, A. Urtti, Undefined role of mucus as a barrier in ocular drug delivery, Eur. J. Pharm. Biopharm. 96 (2015) 442-446. https://doi.org/10.1016/J.EJPB.2015.02.032.

[28] A. Popov, Mucus-Penetrating Particles and the Role of Ocular Mucus as a Barrier to Microand Nanosuspensions, J. Ocul. Pharmacol. Ther. (2020) jop.2020.0022. https://doi.org/10.1089/jop.2020.0022.

[29] J. Leal, H.D.C. Smyth, D. Ghosh, Physicochemical properties of mucus and their impact on transmucosal drug delivery, Int. J. Pharm. 532 (2017) 555-572. https://doi.org/10.1016/J.IJPHARM.2017.09.018.

[30] S.K. Gade, N. Shivshetty, N. Sharma, S. Bhatnagar, P. Garg, V.V.K. Venuganti, Effect of Mucoadhesive Polymeric Formulation on Corneal Permeation of Fluoroquinolones, J. Ocul. Pharmacol. Ther. 34 (2018) 570-578. https://doi.org/10.1089/jop.2018.0059.

[31] D. Sensoy, E. Cevher, A. Sarici, M. Yilmaz, A. Ozdamar, N. Bergişadi, Bioadhesive sulfacetamide sodium microspheres: evaluation of their effectiveness in the treatment of bacterial keratitis caused by Staphylococcus aureus and Pseudomonas aeruginosa in a rabbit model., Eur. J. Pharm. Biopharm. 72 (2009) 487-95. https://doi.org/10.1016/j.ejpb.2009.02.006.

[32] R.S. Bhatta, H. Chandasana, Y.S. Chhonker, C. Rathi, D. Kumar, K. Mitra, P.K. Shukla, Mucoadhesive nanoparticles for prolonged ocular delivery of natamycin: In vitro and pharmacokinetics studies, Int. J. Pharm. 432 (2012) 105-112. https://doi.org/10.1016/J.IJPHARM.2012.04.060.

[33] A. Fabiano, P. Chetoni, Y. Zambito, Mucoadhesive nano-sized supramolecular assemblies for improved pre-corneal drug residence time, Drug Dev. Ind. Pharm. 41 (2015) 2069-2076. https://doi.org/10.3109/03639045.2015.1066798.

[34] E. Ramsay, E.M. del Amo, E. Toropainen, U. Tengvall-Unadike, V.-P. Ranta, A. Urtti, M. Ruponen, Corneal and conjunctival drug permeability: Systematic comparison and pharmacokinetic impact in the eye, Eur. J. Pharm. Sci. 119 (2018) 83-89. https://doi.org/10.1016/J.EJPS.2018.03.034.

[35] C.S. Nowell, F. Radtke, Corneal epithelial stem cells and their niche at a glance, J. Cell Sci. 130 (2017) 1021-1025. https://doi.org/10.1242/JCS.198119.

[36] G. Sahay, D.Y. Alakhova, A. V. Kabanov, Endocytosis of nanomedicines, J. Control. Release. 145 
(2010) 182-195. https://doi.org/10.1016/J.JCONREL.2010.01.036.

[37] K.M. Association for Research in Vision and Ophthalmology., K. Kananen, S. Auriola, K. Kontturi, A. Urtti, Characterization of paracellular and aqueous penetration routes in cornea, conjunctiva, and sclera., Invest. Ophthalmol. Vis. Sci. 38 (1997) 627-634.

https://iovs.arvojournals.org/article.aspx?articleid=2161463 (accessed June 26, 2020).

[38] E. Mannermaa, K.-S. Vellonen, A. Urtti, Drug transport in corneal epithelium and blood-retina barrier: Emerging role of transporters in ocular pharmacokinetics, Adv. Drug Deliv. Rev. 58 (2006) 1136-1163. https://doi.org/10.1016/J.ADDR.2006.07.024.

[39] J. Liaw, Y. Rojanasakul, J.R. Robinson, The effect of drug charge type and charge density on corneal transport, Int. J. Pharm. 88 (1992) 111-124. https://doi.org/10.1016/03785173(92)90308-0.

[40] S.E. Wilson, J.W. Hong, Bowman's layer structure and function: critical or dispensable to corneal function? A hypothesis., Cornea. 19 (2000) 417-20. https://doi.org/10.1097/00003226-200007000-00001.

[41] E.P. Holowka, S.K. Bhatia, Thin-Film Materials, in: Drug Deliv., Springer New York, New York, NY, 2014: pp. 63-116. https://doi.org/10.1007/978-1-4939-1998-7_3.

[42] A. Ben-Zvi, M.M. Rodrigues, J.H. Krachmer, L.S. Fujikawa, Immunohistochemical characterization of extracellular matrix in the developing human cornea, Curr. Eye Res. 5 (1986) 105-117. https://doi.org/10.3109/02713688609015099.

[43] D.E. Birk, J.M. Fitch, J.P. Babiarz, T.F. Linsenmayer, Collagen type I and type $V$ are present in the same fibril in the avian corneal stroma., J. Cell Biol. 106 (1988) 999-1008. https://doi.org/10.1083/jcb.106.3.999.

[44] M.R. Prausnitz, J.S. Noonan, Permeability of cornea, sclera, and conjunctiva: A literature analysis for drug delivery to the eye, J. Pharm. Sci. 87 (1998) 1479-1488. https://doi.org/10.1021/JS9802594.

[45] U. Labermeier, T.A. Demlow, M.C. Kenney, Identification of collagens isolated from bovine Descemet's membrane, Exp. Eye Res. 37 (1983) 225-237. https://doi.org/10.1016/00144835(83)90157-4.

[46] W. Ishizaki, M; Westerhausen-Larson, A; Kino, J; Hayashi, T;Kao, Distribution of collagen IV in human ocular tissues, Invest. Ophthalmol. Vis. Sci. 34 (1993) 2680-2689. https://iovs.arvojournals.org/article.aspx?articleid=2160867 (accessed June 27, 2020).

[47] J.A. Last, S.J. Liliensiek, P.F. Nealey, C.J. Murphy, Determining the mechanical properties of human corneal basement membranes with atomic force microscopy., J. Struct. Biol. 167 (2009) 19-24. https://doi.org/10.1016/j.jsb.2009.03.012.

[48] M. Fannon, K. Forsten-Williams, B. Zhao, E. Bach, P.P. Parekh, C.L. Chu, A.L. Goerges-Wildt, J.A. Buczek-Thomas, M.A. Nugent, Facilitated diffusion of VEGF165 through descemet's membrane with sucrose octasulfate, J. Cell. Physiol. 227 (2012) 3693-3700. https://doi.org/10.1002/jcp.24077.

[49] V. Beaulieu Leclerc, O. Roy, K. Santerre, S. Proulx, TGF- $\beta 1$ promotes cell barrier function upon maturation of corneal endothelial cells, Sci. Rep. 8 (2018) 4438. https://doi.org/10.1038/s41598-018-22821-9.

[50] K.J. Mandell, G.P. Holley, C.A. Parkos, H.F. Edelhauser, Antibody Blockade of Junctional Adhesion Molecule-A in Rabbit Corneal Endothelial Tight Junctions Produces Corneal Swelling, Investig. Opthalmology Vis. Sci. 47 (2006) 2408. https://doi.org/10.1167/iovs.05-0745.

[51] M. Durymanov, J. Reineke, Non-viral Delivery of Nucleic Acids: Insight Into Mechanisms of Overcoming Intracellular Barriers., Front. Pharmacol. 9 (2018) 971. https://doi.org/10.3389/fphar.2018.00971.

[52] G.A. de Souza, L.M. Godoy, M. Mann, Identification of 491 proteins in the tear fluid proteome reveals a large number of proteases and protease inhibitors, Genome Biol. 7 (2006) R72. https://doi.org/10.1186/GB-2006-7-8-R72.

[53] T.N. Yusifov, A.R. Abduragimov, K. Narsinh, O.K. Gasymov, B.J. Glasgow, Tear lipocalin is the major endonuclease in tears, Mol. Vis. 14 (2008) 180. 
https://www.ncbi.nlm.nih.gov/pmc/articles/PMC2254967/ (accessed July 20, 2020).

[54] H. Yin, R.L. Kanasty, A.A. Eltoukhy, A.J. Vegas, J.R. Dorkin, D.G. Anderson, Non-viral vectors for gene-based therapy, Nat. Rev. Genet. 15 (2014) 541-555. https://doi.org/10.1038/nrg3763.

[55] C. Cursiefen, E. Viaud, F. Bock, B. Geudelin, A. Ferry, P. Kadlecová, M. Lévy, S. Al Mahmood, S. Colin, E. Thorin, F. Majo, B. Frueh, F. Wilhelm, T. Meyer-Ter-Vehn, G. Geerling, D. Böhringer, T. Reinhard, D. Meller, U. Pleyer, B. Bachmann, B. Seitz, Aganirsen Antisense Oligonucleotide Eye Drops Inhibit Keratitis-Induced Corneal Neovascularization and Reduce Need for Transplantation: The I-CAN Study, Ophthalmology. 121 (2014) 1683-1692. https://doi.org/10.1016/J.OPHTHA.2014.03.038.

[56] J.M. Benitez-Del-Castillo, J. Moreno-Montañés, I. Jiménez-Alfaro, F.J. Muñoz-Negrete, K. Turman, K. Palumaa, B. Sádaba, M.V. González, V. Ruz, B. Vargas, C. Pañeda, T. Martínez, A.M. Bleau, A.I. Jimenez, Safety and Efficacy Clinical Trials for SYL1001, a Novel Short Interfering RNA for the Treatment of Dry Eye Disease, Investig. Opthalmology Vis. Sci. 57 (2016) 6447. https://doi.org/10.1167/iovs.16-20303.

[57] V. Gonzalez, V. Ruz, A.M. Bleau, B. Vargas, A.I. Jimenez, Tivanisiran as a new treatment for Dry Eye in patients with Sjögren Syndrome, Invest. Ophthalmol. Vis. Sci. 61 (2020) 102-102. https://iovs.arvojournals.org/article.aspx?articleid=2769224.

[58] I. Ruseska, A. Zimmer, Internalization mechanisms of cell-penetrating peptides, Beilstein J. Nanotechnol. 11 (2020) 101-123. https://doi.org/10.3762/bjnano.11.10.

[59] L.N. Johnson, S.M. Cashman, R. Kumar-Singh, Cell-penetrating Peptide for Enhanced Delivery of Nucleic Acids and Drugs to Ocular Tissues Including Retina and Cornea, Mol. Ther. 16 (2008) 107-114. https://doi.org/10.1038/SJ.MT.6300324.

[60] L.N. Johnson, S.M. Cashman, S.P. Read, R. Kumar-Singh, Cell penetrating peptide POD mediates delivery of recombinant proteins to retina, cornea and skin, Vision Res. 50 (2010) 686-697. https://doi.org/10.1016/J.VISRES.2009.08.028.

[61] F. Joris, L. De Backer, T. Van de Vyver, C. Bastiancich, S.C. De Smedt, K. Raemdonck, Repurposing cationic amphiphilic drugs as adjuvants to induce lysosomal siRNA escape in nanogel transfected cells, J. Control. Release. 269 (2018) 266-276.

https://doi.org/10.1016/J.JCONREL.2017.11.019.

[62] T. Van de Vyver, B. Bogaert, L. De Backer, F. Joris, R. Guagliardo, J. Van Hoeck, P. Merckx, S. Van Calenbergh, S. Ramishetti, D. Peer, K. Remaut, S.C. De Smedt, K. Raemdonck, Cationic Amphiphilic Drugs Boost the Lysosomal Escape of Small Nucleic Acid Therapeutics in a Nanocarrier-Dependent Manner, ACS Nano. 14 (2020) 4774-4791. https://doi.org/10.1021/acsnano.0c00666.

[63] F. Joris, S.C. De Smedt, K. Raemdonck, Small molecules convey big messages: Boosting nonviral nucleic acid delivery with low molecular weight drugs, Nano Today. 16 (2017) 14-29. https://doi.org/10.1016/J.NANTOD.2017.06.012.

[64] D. Schiroli, M.J. Gómara, E. Maurizi, S.D. Atkinson, L. Mairs, K.A. Christie, D.F. Cobice, C.M. McCrudden, M.A. Nesbit, I. Haro, T. Moore, Effective In Vivo Topical Delivery of siRNA and Gene Silencing in Intact Corneal Epithelium Using a Modified Cell-Penetrating Peptide, Mol. Ther. - Nucleic Acids. 17 (2019) 891-906. https://doi.org/10.1016/J.OMTN.2019.07.017.

[65] H.N. Bernstein, Chloroquine ocular toxicity., Surv. Ophthalmol. 12 (1967) 415-447.

[66] F. Zahir-Jouzdani, M. Soleimani, M. Mahbod, F. Mottaghitalab, F. Vakhshite, E. Arefian, S. Shahhoseini, R. Dinarvand, F. Atyabi, Corneal chemical burn treatment through a delivery system consisting of TGF- $\beta 1$ siRNA: in vitro and in vivo, Drug Deliv. Transl. Res. 8 (2018) 11271138. https://doi.org/10.1007/s13346-018-0546-0.

[67] M. Goel, R.G. Picciani, R.K. Lee, S.K. Bhattacharya, Aqueous humor dynamics: a review., Open Ophthalmol. J. 4 (2010) 52-9. https://doi.org/10.2174/1874364101004010052.

[68] W. Yuan, H. Li, Polymer-based nanocarriers for therapeutic nucleic acids delivery, Nanostructures Drug Deliv. (2017) 445-460. https://doi.org/10.1016/B978-0-323-461436.00014-2.

[69] P. Baran-Rachwalska, N. Torabi-Pour, F.M. Sutera, M. Ahmed, K. Thomas, M.A. Nesbit, M. 
Welsh, C.B.T. Moore, S.R. Saffie-Siebert, Topical siRNA delivery to the cornea and anterior eye by hybrid silicon-lipid nanoparticles, J. Control. Release. 326 (2020) 192-202.

https://doi.org/10.1016/J.JCONREL.2020.07.004.

[70] D. Bouard, D. Alazard-Dany, F.-L. Cosset, Viral vectors: from virology to transgene expression., Br. J. Pharmacol. 157 (2009) 153-65. https://doi.org/10.1038/bjp.2008.349.

[71] US Food and Drug Administration, FDA approves novel gene therapy to treat patients with a rare form of inherited vision loss | FDA, (2017). https://www.fda.gov/news-events/pressannouncements/fda-approves-novel-gene-therapy-treat-patients-rare-form-inherited-visionloss (accessed July 24, 2020).

[72] S.M. Hoy, Onasemnogene Abeparvovec: First Global Approval, Drugs. 79 (2019) 1255-1262. https://doi.org/10.1007/s40265-019-01162-5.

[73] G. Karponi, N. Zogas, Gene Therapy For Beta-Thalassemia: Updated Perspectives., Appl. Clin. Genet. 12 (2019) 167-180. https://doi.org/10.2147/TACG.S178546.

[74] C.A. Challener, Seeking Solutions for Large-Scale GMP Viral Vector Manufacturing, Pharm. Technol. 43 (2019) 22-26.

[75] K. Tsubota, H. Inoue, K. Ando, M. Ono, K. Yoshino, I. Saito, Adenovirus-Mediated Gene Transfer to the Ocular Surface Epithelium, Exp. Eye Res. 67 (1998) 531-538. https://doi.org/10.1006/EXER.1998.0557.

[76] I.-J. Wang, M.-C. Jhuang, Y.-H. Chen, L.-K. Yeh, C.-Y. Liu, T.-H. Young, Chitosan Modification of Adenovirus to Modify Transfection Efficiency in Bovine Corneal Epithelial Cells, PLoS One. 5 (2010) e12085. https://doi.org/10.1371/journal.pone.0012085.

[77] B. Spencer, S. Agarwala, M. Miskulin, M. Smith, C.R. Brandt, Herpes simplex virus-mediated gene delivery to the rodent visual system., Invest. Ophthalmol. Vis. Sci. 41 (2000) 1392-1401.

[78] M. Silva, R. Calado, J. Marto, A. Bettencourt, A. Almeida, L. Gonçalves, Chitosan Nanoparticles as a Mucoadhesive Drug Delivery System for Ocular Administration, Mar. Drugs. 15 (2017) 370. https://doi.org/10.3390/md15120370.

[79] W. Chaiyasan, S.P. Srinivas, W. Tiyaboonchai, Mucoadhesive Chitosan-Dextran Sulfate Nanoparticles for Sustained Drug Delivery to the Ocular Surface, J. Ocul. Pharmacol. Ther. 29 (2013) 200-207. https://doi.org/10.1089/jop.2012.0193.

[80] E. Sokołowska, A.U. Błachnio-Zabielska, A Critical Review of Electroporation as A Plasmid Delivery System in Mouse Skeletal Muscle, Int. J. Mol. Sci. 20 (2019). https://doi.org/10.3390/IJMS20112776.

[81] J. Shi, Y. Ma, J. Zhu, Y. Chen, Y. Sun, Y. Yao, Z. Yang, J. Xie, A Review on Electroporation-Based Intracellular Delivery, Molecules. 23 (2018). https://doi.org/10.3390/MOLECULES23113044.

[82] K. Blair-Parks, B.C. Weston, D.A. Dean, High-level gene transfer to the cornea using electroporation, J. Gene Med. 4 (2002) 92-100. https://doi.org/10.1002/jgm.231.

[83] R. Zhou, D.A. Dean, Gene transfer of interleukin 10 to the murine cornea using electroporation, Exp. Biol. Med. 232 (2007) 362-369. https://doi.org/10.3181/00379727-2322320362.

[84] M.T.S. Lin, L. Pulkkinen, J. Uitto, K. Yoon, The gene gun: current applications in cutaneous gene therapy, Int. J. Dermatol. 39 (2000) 161-170. https://doi.org/10.1046/j.13654362.2000.00925.x.

[85] D.L. Tanelian, M.A. Barry, S.A. Johnston, T. Le, G. Smith, Controlled Gene Gun Delivery and Expression of DNA Within the Cornea, Biotechniques. 23 (1997) 484-488. https://doi.org/10.2144/97233st06.

[86] E.-P. Zhang, A. Müller, F. Schulte, S.A. König Merediz, F. Sack, C. Junghans, B. Wittig, F. Hoffmann, Minimizing side effects of ballistic gene transfer into the murine corneal epithelium, Graefe's Arch. Clin. Exp. Ophthalmol. 240 (2002) 114-119. https://doi.org/10.1007/s00417-001-0411-5.

[87] D. Bauer, M. Lu, S. Wasmuth, H. Li, Y. Yang, M. Roggendorf, K.P. Steuhl, A. Heiligenhaus, Immunomodulation by topical particle-mediated administration of cytokine plasmid DNA suppresses herpetic stromal keratitis without impairment of antiviral defense, Graefe's Arch. 
Clin. Exp. Ophthalmol. 244 (2006) 216-225. https://doi.org/10.1007/s00417-005-0070-z.

[88] A. Shiraishi, R.L. Converse, C.Y. Liu, F. Zhou, C.W. Kao, W.W. Kao, Identification of the corneaspecific keratin 12 promoter by in vivo particle-mediated gene transfer., Invest. Ophthalmol. Vis. Sci. 39 (1998) 2554-2561. https://iovs.arvojournals.org/article.aspx?articleid=2161680 (accessed July 2, 2020).

[89] I.S. Zagon, J.W. Sassani, K.J. Malefyt, P.J. McLaughlin, Regulation of Corneal Repair by ParticleMediated Gene Transfer of Opioid Growth Factor Receptor Complementary DNA, Arch. Ophthalmol. 124 (2006) 1620. https://doi.org/10.1001/archopht.124.11.1620.

[90] B. D, W. S, L. M, H. A, Particle-mediated Administration of Plasmid DNA on Corneas of BALB/C Mice, Methods Mol. Biol. 940 (2013). https://doi.org/10.1007/978-1-62703-110-3_18.

[91] W.T. Godbey, W.T. Godbey, Gene Delivery, An Introd. to Biotechnol. (2014) 275-312. https://doi.org/10.1016/B978-1-907568-28-2.00013-7.

[92] N.S. Abdelfattah, M. Amgad, A.A. Zayed, H. Salem, A.E. Elkhanany, H. Hussein, N. Abd El-Baky, Clinical correlates of common corneal neovascular diseases: a literature review., Int. J. Ophthalmol. 8 (2015) 182-93. https://doi.org/10.3980/j.issn.2222-3959.2015.01.32.

[93] W. Philipp, L. Speicher, C. Humpel, Expression of vascular endothelial growth factor and its receptors in inflamed and vascularized human corneas., Invest. Ophthalmol. Vis. Sci. 41 (2000) 2514-22. http://www.ncbi.nlm.nih.gov/pubmed/10937562 (accessed August 9, 2020).

[94] L. Zuo, Y. Fan, F. Wang, Q. Gu, X. Xu, A SiRNA Targeting Vascular Endothelial Growth Factor-A Inhibiting Experimental Corneal Neovascularization, Curr. Eye Res. 35 (2010) 375-384. https://doi.org/10.3109/02713681003597230.

[95] N. Singh, E. Higgins, S. Amin, P. Jani, E. Richter, A. Patel, R. Kaur, J. Wang, J. Ambati, Z. Dong, B.K. Ambati, Unique homologous siRNA blocks hypoxia-induced VEGF upregulation in human corneal cells and inhibits and regresses murine corneal neovascularization., Cornea. 26 (2007) 65-72. https://doi.org/10.1097/ICO.0b013e31802b4201.

[96] B. Kim, Q. Tang, P.S. Biswas, J. Xu, R.M. Schiffelers, F.Y. Xie, A.M. Ansari, P. V. Scaria, M.C. Woodle, P. Lu, B.T. Rouse, Inhibition of Ocular Angiogenesis by siRNA Targeting Vascular Endothelial Growth Factor Pathway Genes: Therapeutic Strategy for Herpetic Stromal Keratitis, Am. J. Pathol. 165 (2004) 2177-2185. https://doi.org/10.1016/S00029440(10)63267-1.

[97] E.A. Azzopardi, E.L. Ferguson, D.W. Thomas, The enhanced permeability retention effect: a new paradigm for drug targeting in infection, J. Antimicrob. Chemother. 68 (2013) 257-274. https://doi.org/10.1093/jac/dks379.

[98] S.K. Golombek, J.-N. May, B. Theek, L. Appold, N. Drude, F. Kiessling, T. Lammers, Tumor targeting via EPR: Strategies to enhance patient responses, Adv. Drug Deliv. Rev. 130 (2018) 17-38. https://doi.org/10.1016/J.ADDR.2018.07.007.

[99] R.M. Schiffelers, G. Storm, ICS-283: a system for targeted intravenous delivery of siRNA, Expert Opin. Drug Deliv. 3 (2006) 445-454. https://doi.org/10.1517/17425247.3.3.445.

[100] J.T. Rodier, R. Tripathi, M.K. Fink, A. Sharma, M. Korampally, S. Gangopadhyay, E.A. Giuliano, P.R. Sinha, R.R. Mohan, Linear Polyethylenimine-DNA Nanoconstruct for Corneal Gene Delivery, J. Ocul. Pharmacol. Ther. 35 (2019) 23-31. https://doi.org/10.1089/jop.2018.0024.

[101] I. Luis de Redín, C. Boiero, S. Recalde, M. Agüeros, D. Allemandi, J.M. Llabot, A. García-Layana, J.M. Irache, In vivo effect of bevacizumab-loaded albumin nanoparticles in the treatment of corneal neovascularization, Exp. Eye Res. 185 (2019) 107697. https://doi.org/10.1016/J.EXER.2019.107697.

[102] S. Grisanti, F. Ziemssen, Bevacizumab: off-label use in ophthalmology., Indian J. Ophthalmol. 55 (2007) 417-20. https://doi.org/10.4103/0301-4738.36474.

[103] T. Bro, M. Derebecka, Ø.K. Jørstad, A. Grzybowski, Off-label use of bevacizumab for wet agerelated macular degeneration in Europe, Graefe's Arch. Clin. Exp. Ophthalmol. 258 (2020) 503-511. https://doi.org/10.1007/s00417-019-04569-8.

[104] J.-G. Sun, Q. Jiang, X.-P. Zhang, K. Shan, B.-H. Liu, C. Zhao, B. Yan, Mesoporous silica nanoparticles as a delivery system for improving antiangiogenic therapy., Int. J. 
Nanomedicine. 14 (2019) 1489-1501. https://doi.org/10.2147/IJN.S195504.

[105] E.C. Carlson, C.-Y. Liu, X. Yang, M. Gregory, B. Ksander, J. Drazba, V.L. Perez, In Vivo Gene Delivery and Visualization of Corneal Stromal Cells Using an Adenoviral Vector and Keratocyte-Specific Promoter, Investig. Opthalmology Vis. Sci. 45 (2004) 2194. https://doi.org/10.1167/iovs.03-1224.

[106] Y. Lu, J. Ai, D. Gessler, Q. Su, K. Tran, Q. Zheng, X. Xu, G. Gao, Efficient Transduction of Corneal Stroma by Adeno-Associated Viral Serotype Vectors for Implications in Gene Therapy of Corneal Diseases, Hum. Gene Ther. 27 (2016) 598-608. https://doi.org/10.1089/hum.2015.167.

[107] Y. Lu, P.W.L. Tai, J. Ai, D.J. Gessler, Q. Su, X. Yao, Q. Zheng, P.D. Zamore, X. Xu, G. Gao, Transcriptome Profiling of Neovascularized Corneas Reveals miR-204 as a Multi-target Biotherapy Deliverable by rAAVs, Mol. Ther. - Nucleic Acids. 10 (2018) 349-360. https://doi.org/10.1016/J.OMTN.2017.12.019.

[108] C. Hippert, S. Ibanes, N. Serratrice, F. Court, F. Malecaze, E.J. Kremer, V. Kalatzis, Corneal Transduction by Intra-Stromal Injection of AAV Vectors In Vivo in the Mouse and Ex Vivo in Human Explants, PLoS One. 7 (2012) e35318. https://doi.org/10.1371/journal.pone.0035318.

[109] M.-L. Tsai, S.-L. Chen, P.-I. Chou, L.-Y. Wen, R.J.-F. Tsai, Y.-P. Tsao, Inducible adeno-associated virus vector-delivered transgene expression in corneal endothelium., Invest. Ophthalmol. Vis. Sci. 43 (2002) 751-757.

[110] B.C. Gilger, E. Crabtree, L. Song, T. Llanga, M. Cullen, A. Blanchard, J. Salmon, S. Patel, V. Zarnitsyn, M. Hirsch, A Fixed-Depth Microneedle Enhances Reproducibility and Safety for Corneal Gene Therapy., Cornea. 39 (2020) 362-369. https://doi.org/10.1097/ICO.0000000000002182.

[111] S. Gupta, J.T. Rodier, A. Sharma, E.A. Giuliano, P.R. Sinha, N.P. Hesemann, A. Ghosh, R.R. Mohan, Targeted AAV5-Smad7 gene therapy inhibits corneal scarring in vivo, PLoS One. 12 (2017) e0172928. https://doi.org/10.1371/JOURNAL.PONE.0172928.

[112] H. Yu, J. Wu, H. Li, Z. Wang, X. Chen, Y. Tian, M. Yi, X. Ji, J. Ma, Q. Huang, Inhibition of corneal neovascularization by recombinant adenovirus-mediated sFlk-1 expression, Biochem. Biophys. Res. Commun. 361 (2007) 946-952. https://doi.org/10.1016/J.BBRC.2007.07.114.

[113] I. Lentacker, I. De Cock, R. Deckers, S.C. De Smedt, C.T.W. Moonen, Understanding ultrasound induced sonoporation: Definitions and underlying mechanisms, Adv. Drug Deliv. Rev. 72 (2014) 49-64. https://doi.org/10.1016/J.ADDR.2013.11.008.

[114] S. Roovers, T. Segers, G. Lajoinie, J. Deprez, M. Versluis, S.C. De Smedt, I. Lentacker, The Role of Ultrasound-Driven Microbubble Dynamics in Drug Delivery: From Microbubble Fundamentals to Clinical Translation, Langmuir. 35 (2019) 10173-10191. https://doi.org/10.1021/acs.langmuir.8b03779.

[115] S. Sirsi, M. Borden, Microbubble Compositions, Properties and Biomedical Applications., Bubble Sci. Eng. Technol. 1 (2009) 3-17. https://doi.org/10.1179/175889709X446507.

[116] S. Sonoda, K. Tachibana, E. Uchino, A. Okubo, M. Yamamoto, K. Sakoda, T. Hisatomi, K.-H. Sonoda, Y. Negishi, Y. Izumi, S. Takao, T. Sakamoto, Gene Transfer to Corneal Epithelium and Keratocytes Mediated by Ultrasound with Microbubbles, Investig. Opthalmology Vis. Sci. 47 (2006) 558. https://doi.org/10.1167/iovs.05-0889.

[117] Y. Oshima, T. Sakamoto, T. Hisatomi, C. Tsutsumi, Y. Sassa, T. Ishibashi, H. Inomata, Targeted Gene Transfer to Corneal Stroma in vivo by Electric Pulses, Exp. Eye Res. 74 (2002) 191-198. https://doi.org/10.1006/EXER.2001.1117.

[118] Y.C. Kim, H.E. Grossniklaus, H.F. Edelhauser, M.R. Prausnitz, Intrastromal Delivery of Bevacizumab Using Microneedles to Treat Corneal Neovascularization, Investig. Opthalmology Vis. Sci. 55 (2014) 7376. https://doi.org/10.1167/iovs.14-15257.

[119] A. Than, C. Liu, H. Chang, P.K. Duong, C.M.G. Cheung, C. Xu, X. Wang, P. Chen, Selfimplantable double-layered micro-drug-reservoirs for efficient and controlled ocular drug delivery, Nat. Commun. 9 (2018) 4433. https://doi.org/10.1038/s41467-018-06981-w.

[120] H. Sun, M. Han, M.H. Niemz, J.F. Bille, Femtosecond laser corneal ablation threshold: 
dependence on tissue depth and laser pulse width., Lasers Surg. Med. 39 (2007) 654-8. https://doi.org/10.1002/lsm.20538.

[121] H.W. Roberts, A.C. Day, D.P. O'Brart, Femtosecond laser-assisted cataract surgery: A review., Eur. J. Ophthalmol. 30 (2020) 417-429. https://doi.org/10.1177/1120672119893291.

[122] L. Mastropasqua, L. Toto, A. Mastropasqua, L. Vecchiarino, R. Mastropasqua, E. Pedrotti, M. Di Nicola, Femtosecond Laser Versus Manual Clear Corneal Incision in Cataract Surgery, J. Refract. Surg. 30 (2014) 27-33. https://doi.org/10.3928/1081597X-20131217-03.

[123] Y.M. Por, J.Y.C. Cheng, A. Parthasarathy, J.S. Mehta, D.T.H. Tan, Outcomes of Femtosecond Laser-Assisted Penetrating Keratoplasty, Am. J. Ophthalmol. 145 (2008) 772-774.e2. https://doi.org/10.1016/J.AJO.2008.01.003.

[124] A.M. Wilson, J. Mazzaferri, É. Bergeron, S. Patskovsky, P. Marcoux-Valiquette, S. Costantino, P. Sapieha, M. Meunier, In Vivo Laser-Mediated Retinal Ganglion Cell Optoporation Using K $v 1.1$ Conjugated Gold Nanoparticles, Nano Lett. 18 (2018) 6981-6988. https://doi.org/10.1021/acs.nanolett.8b02896.

[125] F. Sauvage, J.C. Fraire, K. Remaut, J. Sebag, K. Peynshaert, M. Harrington, F.J. Van de Velde, R. Xiong, M.-J. Tassignon, T. Brans, K. Braeckmans, S.C. De Smedt, Photoablation of Human Vitreous Opacities by Light-Induced Vapor Nanobubbles, ACS Nano. 13 (2019) 8401-8416. https://doi.org/10.1021/acsnano.9b04050.

[126] U.K. Tirlapur, K. König, Targeted transfection by femtosecond laser., Nature. 418 (2002) 2901. https://doi.org/10.1038/418290a.

[127] M. Waleed, S.-U. Hwang, J.-D. Kim, I. Shabbir, S.-M. Shin, Y.-G. Lee, Single-cell optoporation and transfection using femtosecond laser and optical tweezers., Biomed. Opt. Express. 4 (2013) 1533-47. https://doi.org/10.1364/BOE.4.001533.

[128] D.J. Stevenson, F.J. Gunn-Moore, P. Campbell, K. Dholakia, Single cell optical transfection., J. R. Soc. Interface. 7 (2010) 863-71. https://doi.org/10.1098/rsif.2009.0463.

[129] S. Vanstone, J.M. Stone, S.N. Gordeev, R.H. Guy, Mechanism of human nail poration by highrepetition-rate, femtosecond laser ablation, Drug Deliv. Transl. Res. 9 (2019) 956-967. https://doi.org/10.1007/s13346-019-00638-x.

[130] H. Garvie-Cook, J.M. Stone, F. Yu, R.H. Guy, S.N. Gordeev, Femtosecond pulsed laser ablation to enhance drug delivery across the skin, J. Biophotonics. 9 (2016) 144-154. https://doi.org/10.1002/jbio.201500120.

[131] A.-P. Bemelmans, Y. Arsenijevic, F. Majo, Efficient lentiviral gene transfer into corneal stroma cells using a femtosecond laser, Gene Ther. 16 (2009) 933-938. https://doi.org/10.1038/gt.2009.41.

[132] I.G. Pallikaris, G.D. Kymionis, A.D. Plaka, P.S. Binder, G.A. Kontadakis, K.I. Tsoulnaras, Femtosecond Laser-Assisted Intra-Corneal Drug Delivery, Semin. Ophthalmol. 30 (2015) 457461. https://doi.org/10.3109/08820538.2013.874482.

[133] A. Budenz, DL; Bennett, J; Alonso, L; Maguire, In vivo gene transfer into murine corneal endothelial and trabecular meshwork cells., Invest. Ophthalmol. Vis. Sci. 36 (1995) 22112215. https://iovs.arvojournals.org/article. aspx?articleid=2161134 (accessed June 29, 2020).

[134] R.J. Tsai, T.T. Sun, S.C. Tseng, Comparison of limbal and conjunctival autograft transplantation in corneal surface reconstruction in rabbits., Ophthalmology. 97 (1990) 446-55. http://www.ncbi.nlm.nih.gov/pubmed/1691476 (accessed April 30, 2019).

[135] J. Bainbridge, C. Stephens, K. Parsley, C. Demaison, A. Halfyard, A. Thrasher, R. Ali, In vivo gene transfer to the mouse eye using an HIV-based lentiviral vector; efficient long-term transduction of corneal endothelium and retinal pigment epithelium, Gene Ther. 8 (2001) 1665-1668. https://doi.org/10.1038/sj.gt.3301574.

[136] V. Gonzales, J. Moreno-Montanes, M. Oll, K.N. Sall, K. Palumaa, H. Dubiner, K. Turman, F. Muñoz-Negrete, V. Ruz, A.I. Jimenez, Results of Phase IIB SYLTAG clinical trial with bamosiran in patients with glaucoma, Invest. Ophthalmol. Vis. Sci. 57 (2016) 3023-3023.

https://iovs.arvojournals.org/article.aspx?articleid=2561359 (accessed July 16, 2020).

[137] T. Martínez, M.V. González, I. Roehl, N. Wright, C. Pañeda, A.I. Jiménez, In Vitro and In Vivo 
Efficacy of SYL040012, a Novel siRNA Compound for Treatment of Glaucoma, Mol. Ther. 22 (2014) 81-91. https://doi.org/10.1038/MT.2013.216.

[138] V.Q. Chau, J. Hu, X. Gong, J.D. Hulleman, R.L. Ufret-Vincenty, F. Rigo, T.P. Prakash, D.R. Corey, V.V. Mootha, Delivery of Antisense Oligonucleotides to the Cornea, Nucleic Acid Ther. 30 (2020) 207-214. https://doi.org/10.1089/nat.2019.0838.

[139] E.J. McGlumphy, J.A. Margo, M. Haidara, C.H. Brown, C.K. Hoover, W.M. Munir, Predictive Value of Corneal Donor Demographics on Endothelial Cell Density, Cornea. 37 (2018) 11591162. https://doi.org/10.1097/ICO.0000000000001664.

[140] T. Hudde, S.A. Rayner, M. De Alwis, A.J. Thrasher, J. Smith, R.S. Coffin, A.J. George, D.F. Larkin, Adeno-associated and herpes simplex viruses as vectors for gene transfer to the corneal endothelium., Cornea. 19 (2000) 369-73. https://doi.org/10.1097/00003226-20000500000022.

[141] L.J. Lai, K.K. Lin, G.N. Foulks, L. Ma, X. Xiao, K.H. Chen, Highly Efficient Ex Vivo Gene Delivery into Human Corneal Endothelial Cells by Recombinant Adeno-Associated Virus, Curr. Eye Res. 30 (2005) 213-219. https://doi.org/10.1080/02713680590927515.

[142] K. Lundstrom, Viral Vectors in Gene Therapy., Dis. (Basel, Switzerland). 6 (2018). https://doi.org/10.3390/diseases6020042.

[143] T. Sakamoto, Y. Oshima, K. Nakagawa, T. Ishibashi, H. Inomata, K. Sueishi, Target Gene Transfer of Tissue Plasminogen Activator to Cornea by Electric Pulse Inhibits Intracameral Fibrin Formation and Corneal Cloudiness, Hum. Gene Ther. 10 (1999) 2551-2557. https://doi.org/10.1089/10430349950016889.

[144] Y. Oshima, T. Sakamoto, I. Yamanaka, T. Nishi, T. Ishibashi, H. Inomata, Targeted gene transfer to corneal endothelium in vivo by electric pulse, Gene Ther. 5 (1998) 1347-1354. https://doi.org/10.1038/sj.gt.3300725.

[145] S. Klebe, J. Stirling, K. Williams, Corneal endothelial cell nuclei are damaged after DNA transfer using a gene gun, Clin. Exp. Ophthalmol. 28 (2000) 58-59. https://doi.org/10.1046/j.14429071.2000.00255.x.

[146] H. Wood, FDA approves patisiran to treat hereditary transthyretin amyloidosis, Nat. Rev. Neurol. 14 (2018) 570-570. https://doi.org/10.1038/s41582-018-0065-0.

[147] K. Lundstrom, T. Boulikas, Viral and non-viral vectors in gene therapy: technology development and clinical trials., Technol. Cancer Res. Treat. 2 (2003) 471-86. https://doi.org/10.1177/153303460300200513.

[148] Y.-P. Jia, B.-Y. Ma, X.-W. Wei, Z.-Y. Qian, The in vitro and in vivo toxicity of gold nanoparticles, Chinese Chem. Lett. 28 (2017) 691-702. https://doi.org/10.1016/J.CCLET.2017.01.021.

[149] N. Zilony, A. Tzur-Balter, E. Segal, O. Shefi, Bombarding cancer: biolistic delivery of therapeutics using porous Si carriers., Sci. Rep. 3 (2013) 2499. https://doi.org/10.1038/srep02499.

[150] P.-W. Lee, S.-F. Peng, C.-J. Su, F.-L. Mi, H.-L. Chen, M.-C. Wei, H.-J. Lin, H.-W. Sung, The use of biodegradable polymeric nanoparticles in combination with a low-pressure gene gun for transdermal DNA delivery, Biomaterials. 29 (2008) 742-751. https://doi.org/10.1016/j.biomaterials.2007.10.034.

[151] B.S. Trembly, Thermal techniques for reshaping the cornea, in: International Society for Optics and Photonics, 2000: p. 1029704. https://doi.org/10.1117/12.375224.

[152] A. Mandal, D. Pal, V. Agrahari, H.M. Trinh, M. Joseph, A.K. Mitra, Ocular delivery of proteins and peptides: Challenges and novel formulation approaches., Adv. Drug Deliv. Rev. 126 (2018) 67-95. https://doi.org/10.1016/j.addr.2018.01.008.

[153] F.E. Pearson, C.L. McNeilly, M.L. Crichton, C.A. Primiero, S.R. Yukiko, G.J.P. Fernando, X. Chen, S.C. Gilbert, A.V.S. Hill, M.A.F. Kendall, Dry-Coated Live Viral Vector Vaccines Delivered by Nanopatch Microprojections Retain Long-Term Thermostability and Induce Transgene-Specific T Cell Responses in Mice, PLoS One. 8 (2013) e67888. https://doi.org/10.1371/journal.pone.0067888.

[154] S.G. Schwartz, H.W. Flynn Jr, T. Das, W.F. Mieler, Ocular Infection: Endophthalmitis, in: Dev. 
Ophthalmol., Karger Publishers, 2016: pp. 176-188. https://doi.org/10.1159/000431195.

[155] H.-J. Jian, R.-S. Wu, T.-Y. Lin, Y.-J. Li, H.-J. Lin, S.G. Harroun, J.-Y. Lai, C.-C. Huang, SuperCationic Carbon Quantum Dots Synthesized from Spermidine as an Eye Drop Formulation for Topical Treatment of Bacterial Keratitis, ACS Nano. 11 (2017) 6703-6716. https://doi.org/10.1021/acsnano.7b01023.

[156] T.J. Duncan, K. Baba, Y. Oie, K. Nishida, A Novel Method Using Quantum Dots for Testing the Barrier Function of Cultured Epithelial Cell Sheets, Investig. Opthalmology Vis. Sci. 56 (2015) 2215. https://doi.org/10.1167/iovs.14-15579. 